Research Article/Araştırma Makalesi

\title{
Three Tier Concept Diagnostic Test Development and Validity Study: Let's Travel and Learn about the Living World Unit of Fifth Grade
}

\author{
Evşen AYMEN PEKER *1 (D) Erol TAŞ ${ }^{2}$ (D) \\ ${ }^{1}$ Tevfik Ileri Imam Hatip Middle School, Samsun, Turkey, evsenaymen@hotmail.com \\ ${ }^{2}$ Ordu University, Faculty of Education, Ordu, Turkey, eroltas@odu.edu.tr \\ * Corresponding Author: evsenaymen@hotmail.com
}

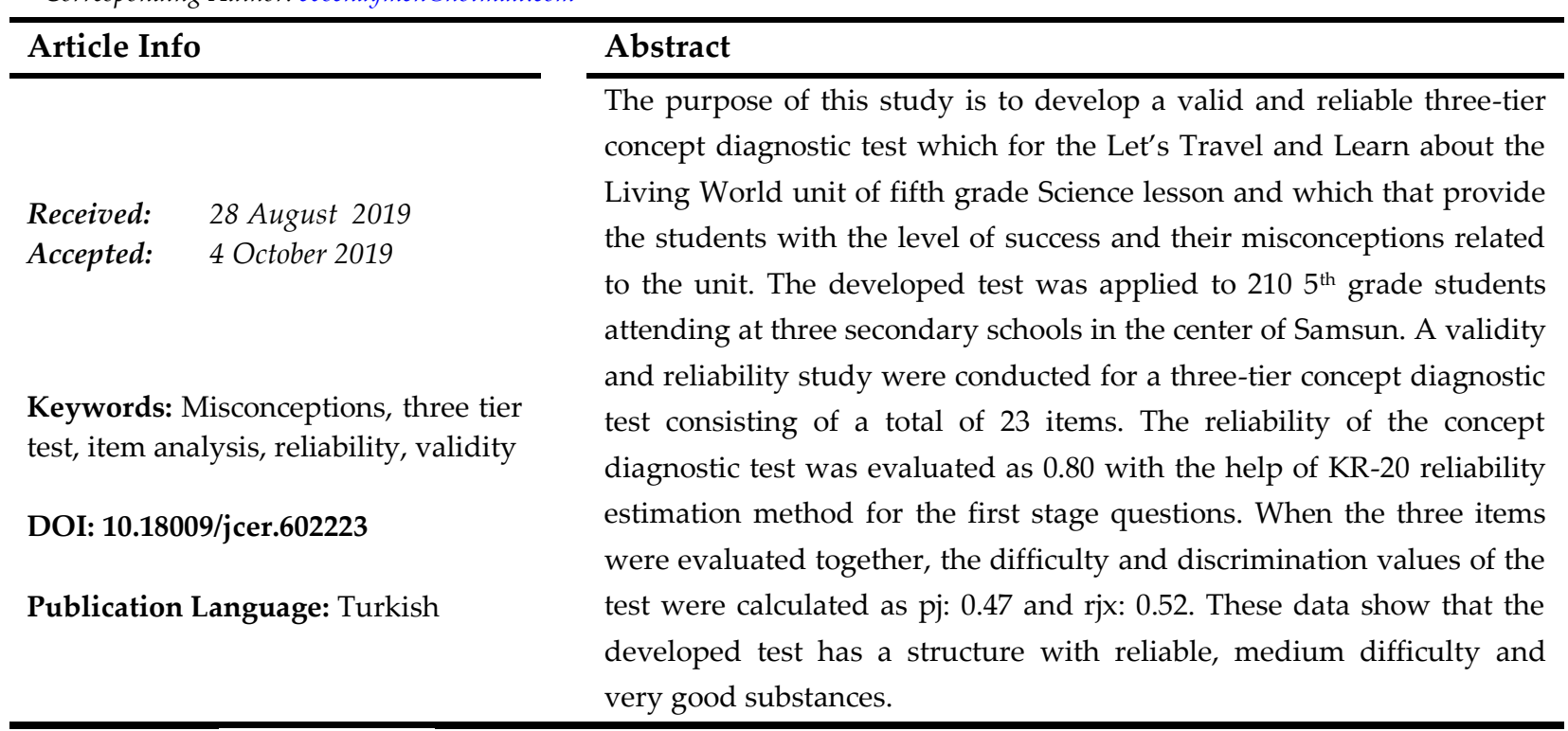
open access ( CrossMark (c) i

To cite this article: Aymen-Peker, E. \& Taş, E. (2019). Investigation of in-school factors affecting distributed leadership practices. Journal of Computer and Education Research, 7(14), 515-539. DOI: $10.18009 /$ jcer.602223

\section{Üç Aşamalı Kavram Tanı Testi Geliştirme ve Geçerlik Çalışması: 5. Sınıf Canlılar Dünyasını Gezelim Tanıyalım Ünitesi}

$\stackrel{\text { Makale Bilgisi }}{ }$ Öz

\section{Geliş: $\quad 28$ A \\ Kabul: $\quad 4$ Ekim 2019}

\begin{abstract}
Anahtar kelimeler: Kavram yanılgısı, üç aşamalı test, madde analizi, geçerlik, güvenirlik
\end{abstract}

DOI: $10.18009 /$ jcer.602223

Yayım Dili: Türkçe
Bu çalışmanın amacı, 5. sınıf fen bilimleri dersi "Canlılar Dünyasını Gezelim ve Tanıyalım" ünitesine yönelik; öğrencilerin ünite ile ilgili başarı düzeyleri ve sahip oldukları kavram yanılgılarının tespit edilmesini sağlayacak geçerli ve güvenilir bir üç aşamalı kavram tanı testi geliştirmektir. Geliştirilen test, Samsun il merkezinde bulunan üç ortaokulda, beşinci sınıfta öğrenim gören 210 öğrenciye uygulanmıştır. Toplam 23 maddeden oluşan üç aşamalı kavram tanı testi için geçerlilik güvenirlik çalışması yapılmıştır. Kavram tanı testinin güvenirliği birinci aşama sorularının analizinden KR-20 formülü ile hesaplanmış ve 0,80 olarak bulunmuştur. Üç madde birlikte değerlendirildiğinde testin güçlük ve ayırt edicilik değerleri sırasıyla pj: 0.47 ve rjx: 0.52 olarak hesaplanmıştır. Bu veriler geliştirilen testin güvenilir, orta güçlükte ve çok iyi maddelerden oluşan bir yapıya sahip olduğunu göstermektedir. 


\section{Summary}

\section{Three Tier Concept Diagnostic Test Development and Validity Study: Let's Travel and Learn about the Living World Unit of Fifth Grade}

\section{Introduction}

Concept is the name given to the groups, when we group things, events, people and thoughts according to their similarities (Yağbasan \& Gülçiçek, 2003). A child begins school life with many concepts that he has learned in the family environment. The child continues his journey of learning concept by encountering many new concepts during his school education. The researches reveal that preliminary knowledge and concepts created outside the school have a huge impact on learning (Novak, 1998).

One of the main objectives of the Science course, in which many concrete and abstract concepts are learned. (Ministry of Education, 2013; 2018), is to enable students to learn the concepts fully and correctly (Köse \& Uşak, 2006). While student learn concepts, depending on both the preliminary knowledge and the experiences that student has in the learning process, he can misconfigure the knowledge scientifically. In such a case, it can be said that the student has misconceptions. However, it can be decided that the student has misconceptions, if the student explains his misconceptions and he is sure of his response (Karataş, Köse \& Coştu, 2003).

When the literature on science education is examined, it is remarkable that students have misconceptions about different learning areas. It is observed that students have misconceptions in the researches about the classification of living things and environmental problems. Researchers such as Allen (2010), Çetinkaya (2010), Mutlu and Tokcan (2012), Özyılmaz-Akamca (2008), Saka, Ayas and Enginar (2002), Summers, Kruger, Childs and Mant (2000), Taş, Aymen Peker and Çetinkaya (2014), Tekkaya, Çapa and Yılmaz (2000), Yen, Yao and Mintzes (2007) have identified students' misconceptions about related topics. 
In order to determine whether the student has misconceptions, tools such as analogy, concept map, concept caricature, prediction-observation-explanation, interview, drawing, word association, $\mathrm{V}$ diagram and misconception diagnostic tests can be used.

It was aimed to develop a valid and reliable measurement tool to determine the achievement levels and misconceptions of the $5^{\text {th }}$ grade students about the "Let's Travel and Learn About The Living World" unit by taking into consideration the 2013 curriculum gains in this study.

\section{Method}

In the study, which was used the Survey method, validity and reliability studies were conducted for the development of "Concept Diagnosis Test". Three-stage process was followed in this study: (1) the development of the first-tier questions of the test, (2) the development of the second and third tier questions of the test and (3) the validity and reliability analysis of the three-tier concept diagnostic test.

Since the Let's Travel and Learn About The Living World unit was applied to 5th grade students for the first time in the 2013-2014 academic year and the Human and Environmental unit was taught at the 7th grade in the 2006 Science and Technology curriculum, test was applied to seventy-three students attending 7th and 8th grade. In the following period, the study was completed with 5th grade. Validity and reliability studies of the test were performed.

In the analysis of the data obtained during the development of the test, for each item, standard deviation, arithmetic mean, item distinctiveness and item difficulty. In the development of first tier test item, item analysis method based on the difference of $27 \%$ subupper group averages and double-series correlation calculation were used. After item analysis was completed, item distinctiveness and item difficulty were calculated. Taking these values into consideration, it was decided which test items should remain in the test.

After completing the elimination of the test's first tier item, the second and third tier questions of the test items were prepared. Three-tier concept diagnosis test was applied to 210 students. Students' responses to test items were first entered into MS Excel. In the 3-tier concept diagnostic test, considering the response to each tier of the question; Peşman and Eryılmaz (2010) and Arslan, Çiğdemoğlu and Moseley (2012) defined eight separate scores were calculated through the macro application developed in MS Excel program. After the 
validity and reliability analysis of the obtained three-tier test, 23-item final three-tier test was obtained.

\section{Results and Discussion}

As a result of the study, a three-tier concept diagnosis test was developed in order to determine the level of grade 5 students' achievements in the Let's Travel and Learn About The Living World unit and what kind of misconceptions they have about this unit. At the same time, validity and reliability analyzes of the test were completed. Although the test was initially developed as 40 questions, the 23-item test was obtained after the analysis was completed. Microsoft Excel and SPSS 17 programs were used for data analysis.

Test reliability was calculated with KR-20 formula; KR-20 reliability level was found to be 0.80 . When the three-tier were evaluated together, the difficulty and discrimination values of the test were calculated as pj: 0.47 and rjx: 0.52 , respectively. These data show that the developed test is reliable, of medium difficulty and composed of very good test items.

Since the three-tier concept diagnosis test provides data on both academic achievement and conceptual diagnosis, it will enable researchers to obtain two separate data sets with a single scale. In the process of determining academic achievement, researchers may consider not only the first-tier questions of the scale, but also the three tiers. Researchers who use the scale to determine misconceptions should evaluate the three tiers together. 


\section{Giriş}

Kavram, nesne ve düşüncelerin insan zihninde canlandırıldığı, soyut bir düşünce birimidir (Yağbasan \& Gülçiçek, 2003). Öğrencilerin Fen Bilimleri derslerinde öğretilen kavramları öğrenme düzeylerini belirleyebilmek için başarı testlerinden yararlanılmaktadır. Açık uçlu testler (Öksüz \& Güven Demir, 2019), kısa cevaplı testler, sınıflama gerektiren testler ile seçim gerektiren çoktan seçmeli testler (Çalık \& Ayas, 2003) öğrencilerin öğretilen kavramları ne düzeyde öğrendiklerini belirlemede kullanılan testler arasında yer almaktadır.

Çoktan seçmeli testler nesnellik, uygulama-değerlendirme kolaylığı ve öğretilen üniteyle ilgili birçok alt kavramın öğrenilme düzeyini belirleme gibi özelliklere sahiptir (Bağcan-Büyükturan \& Çıkrıkçı Demirtaşl1, 2012). Bu testlerde öğrencinin doğru seçeneği işaretlemesi, onun ilgili soruya yönelik bilgisinin tam ve doğru olması anlamına gelmediği gibi, bilgi eksikliği veya yaptığı bazı hatalardan dolayı çeldirici bulunan yanlış seçeneği işaretlemesi de kavram yanılgısına sahip olduğu anlamına gelmemektedir. Bir öğrencinin kavram yanılgısına sahip olduğuna karar verilebilmesi için, öğrencinin sahip olduğu kavram yanılgısını açıklaması ve verdiği yanıttan emin olması gerekmektedir. (Karataş ve di $\breve{g}$., 2003). Çoktan seçmeli testlerin olumlu yönlerini taşıdığı gibi, olumsuzluklarını en aza indirdiği düşünüldüğü için kavram yanılgılarını belirlemek amacıyla 1980'li yıllarda iki aşamalı teşhis testleri geliştirilmeye başlanmıştır (Bernhisel, 1999; Chen, Lin \& Lin, 2002; Odom \& Barrow, 1995; Tan, Goh, Chia \& Treagust, 2002). İki aşamalı kavram tanı testlerinin birinci aşamasında verilen yanıtın, ikinci aşamada nedenleri ile açıklanması istenmektedir (Karataş ve diğ., 2003).

Günümüzde ise öğrencilerin sahip oldukları kavram yanılgılarını belirlemek amacıyla üç aşamalı teşhis testleri kullanılmaya başlanmıştır. Bu testlerin ilk iki aşaması iki aşamalı teşhis testlerinin özelliklerine sahiptir. Üçüncü aşamada öğrencinin ilk iki aşamada verdiği yanıttan ne derecede emin olduğu sorgulanmaktadır. 3-aşamalı kavram tanı testlerinde öğrenci üç aşamada yer alan tüm sorularda kavram yanılgısına götüren seçenekleri işaretlediğinde, öğrencinin kavram yanılgısına sahip olduğu kabul edilmekte, ilk iki aşamada kavram yanılgısına götüren seçenekler işaretlenmesine rağmen, öğrenci bu seçimleri emin olmayarak işaretlediğinde bu durum bilgi eksikliği olarak tanımlanmaktadır (Peşman \& Eryılmaz, 2010).

Fen Bilimleri eğitiminde somut ve soyut birçok kavram öğretilmektedir. Literatür incelendiğinde öğrencilerin, farklı öğrenme alanları ile ilgili kavram yanılgılarının olduğu 
dikkat çekmektedir. Canlıların sınıflandırılması ve çevre sorunları konuları ile ilgili yapılan araştırmalarda öğrencilerin kavram yanılgılarına sahip oldukları gözlenmektedir. Allen (2010), Çetinkaya (2010), Mutlu ve Tokcan (2012), Özyılmaz Akamca (2008), Saka, Ayas ve Enginar (2002), Summers, Kruger, Childs ve Mant (2000), Taş, Aymen Peker ve Çetinkaya (2014), Tekkaya, Çapa ve Yılmaz (2000) ile Yen, Yao ve Mintzes (2007) gibi araştırmacılar ilgili konulara yönelik öğrencilerin sahip oldukları kavram yanılgılarını belirlemiştir. Araştırmalarda daha çok canlıların sınıflandırılması konusu ile ilgili kavram yanılgılarının belirlendiği dikkat çekmektedir. 5. sınıf öğrencileri ile yürütülen çalışmaların ise 2013 öğretim programı öncesinde gerçekleştirildiği ve sadece canlıların sınıflandırılması konusu ile ilgili kavram yanılgılarının belirlendiği gözlenmektedir.

Bu çalışmanın amacı 2013 öğretim programı kazanımları göz önünde bulundurularak ortaokul 5. sınıf öğrencilerinin Canlılar Dünyasını Gezelim ve Tanıalım ünitesi kazanımlarına ne düzeyde ulaştıklarını ve ünite ile ilgili ne tür kavram yanılgılarına sahip olduklarının tespit edilmesini sağlayacak geçerli ve güvenilir bir ölçme aracı geliştirmektir.

\section{Yöntem}

\section{Araştırma Modeli}

Tarama (Survey) yönteminin kullanıldığı bu çalışmada ortaokul 5.sınıf Canlılar Dünyasın Gezelim Tanıyalım ünitesine yönelik Kavram Tanı Testi (KTT) geliştirilmiştir. Test geliştirme sürecinde Şekil 1'de açılanan işlem basamakları takip edilmiştir. Veri analizlerinde Microsoft Excel ve SPSS 17 programlarından yararlanılmıştır. Aritmetik ortalama ve standart sapma değerleri hesaplanan ölçek maddelerine \%27'lik alt-üst grup ortalamaları farkına dayalı madde analizi uygulanmış, SPSS programı ile çift serili korelasyon değerleri hesaplanmıştır. Testin güvenilirliğini tespit etmede KR20 güvenirlik katsayısından yararlanılmıştır. Test geliştirme sürecinde öncelikle birinci aşama soruları için geçerlik güvenirlik çalışmaları yapılmış, birinci aşama soruları tespit edildikten sonra üç aşamalı test için analiz işlemleri tekrarlanmıştır.

\section{Örneklem}

Canlılar Dünyasını Gezelim ve Tanıyalım ünitesi, 2013-2014 eğitim öğretim yılında 5. sınıf öğrencilerine ilk kez uygulandığı ve 2006 yılı Fen ve Teknoloji dersi öğretim programında İnsan ve Çevre ünitesi yedinci sınıf seviyesinde yer aldığı için denemelik test 7.ve 8.sınıf öğrencilerine uygulanmıştır. Daha sonraki aşamalarda 5.sınıf öğrencileri ile 
çalışma tamamlanarak, testin geçerlik ve güvenirlik çalışmaları gerçekleştirilmiştir. Çalışma gruplarına ait bilgiler Tablo 1'de yer almaktadır.

Tablo 1.Test geliştirme aşaması katılımcı bilgileri

\begin{tabular}{llllll}
\hline Test & Öğretim Yılı & Okul & Sınıf Seviyesi & Öğrenci Sayısı & Madde Sayısı \\
\hline Tek Aşamalı test & $2013-2014$ & A & 7. ve 8.sınıf & 73 & 40 \\
İki Aşamalı Nihai Test & $2013-2014$ & A & 5.sınıf & 62 & 30 \\
Üç Aşamalı Test & $2014-2015$ & A, B, C & 5.sınıf & 210 & 25 \\
\hline
\end{tabular}

\section{Bulgular}

\section{KTT Geliştirme Süreci}

Çelik (2000) test geliştirilirken izlenmesi gereken adımları planlama, madde yazma, madde analizi ve madde seçimi şeklinde sıralamaktadır. Çoktan seçmeli başarı testi (Bakioğlu, Karamustafaoğlu \& Karamustafaoğlu, 2014; Çalık \& Ayas, 2003), iki aşamalı (Sesli \& Kara, 2012) ve üç aşamalı kavram tanı testi (Peşman, 2005; Peşman \& Eryılmaz, 2010) geliştirilme süreci ile ilgili araştırmalar incelenip, test geliştirme sürecinde izlenecek adımlar belirlenmiştir (Şekil 1).

a. Kavram tanı testinin birinci aşama sorularının geliştirilmesi

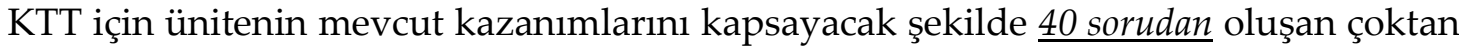
seçmeli denemelik test üç Fen Bilimleri öğretmeni ve üç uzman görüşü alınarak oluşturulmuştur.

Geliştirilen akademik başarı testi, test maddelerinin ünitede yer alan konulara ve kazanımlara göre dağılımı Tablo 2' de yer almaktadır.

Tablo 2. Taslak KTT'de yer alan soru maddelerinin konulara ve kazanımlara göre dağılımı

\begin{tabular}{|c|c|c|c|}
\hline Konular & Kazanımlar & Madde Numarası & Madde Sayısı \\
\hline \multirow{5}{*}{$\begin{array}{l}\text { Canlıları } \\
\text { Tanıyalım } \\
\text { İnsan ve } \\
\text { Çevre İlişkisi }\end{array}$} & 5.5.1.1. Canlılara örnekler vererek benzerlik ve & $1,2,3,4,5,6,7,8,9,10$ & 19 \\
\hline & farklılıklarına göre gruplandırır. & $11,12,13,14,15,16,17,18,23$ & \\
\hline & 5.5.2.1. İnsan faaliyetleri sonucunda oluşan çevre & $20,21,22,26,27,28,29,30,31$, & 16 \\
\hline & $\begin{array}{l}\text { sorunlarını araştırır ve bu sorunların çözümüne } \\
\text { ilişkin önerilerde bulunur. }\end{array}$ & $32,33,34,35,36,37,40$ & \\
\hline & $\begin{array}{l}\text { 5.5.2.2. Yakın çevresindeki bir çevre sorununun } \\
\text { çözümüne ilişkin proje tasarlar ve sunar. }\end{array}$ & $19,24,25,38,39$ & 5 \\
\hline
\end{tabular}




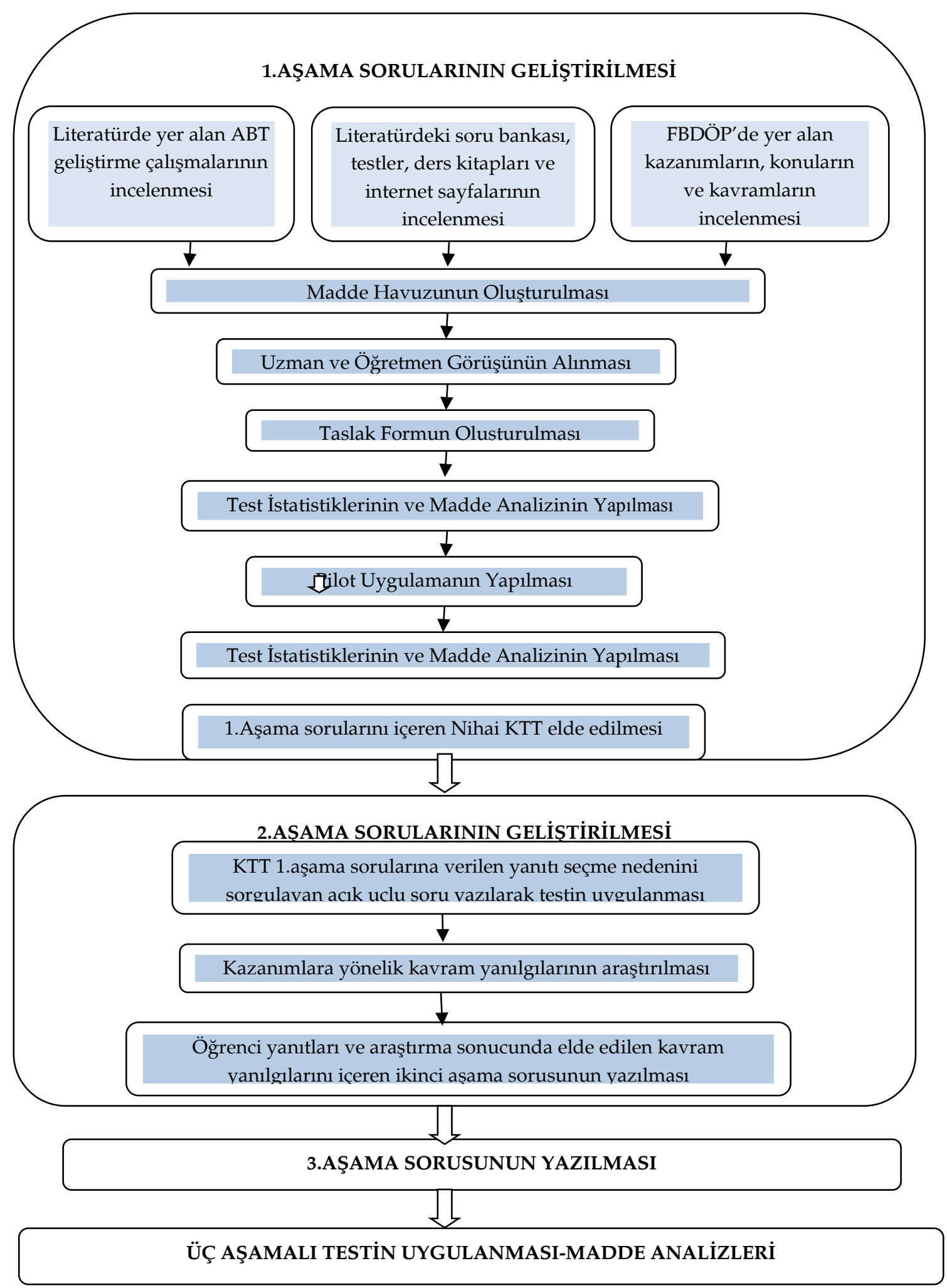

Şekil 1. Kavram tanı testi geliştirme süreci

Tablo 3'de taslak KTT ilk uygulama- test maddelerinin aritmetik ortalama ve standart sapma değerleri verilmiştir 
Tablo 3. Taslak KTT ilk uygulama-soruların aritmetik ortalama-standart sapma değerleri

\begin{tabular}{|c|c|c|c|c|c|c|c|c|c|c|c|c|c|c|c|}
\hline$\frac{\frac{\pi}{\pi}}{\frac{\pi}{\pi}}$ & $\mathbf{N}$ & $\bar{x}$ & SS & $\frac{\tilde{z}}{\frac{\pi}{\pi}}$ & $\mathbf{N}$ & $\bar{x}$ & SS & $\frac{\pi}{\frac{\pi}{\pi}}$ & $\mathbf{N}$ & $\overline{\boldsymbol{x}}$ & SS & $\frac{\pi}{\frac{\pi}{\pi}}$ & $\mathbf{N}$ & $\overline{\boldsymbol{x}}$ & SS \\
\hline 1 & 73 & 0.96 & 0.20 & 11 & 73 & 0.85 & 0.36 & 21 & 73 & 0.84 & 0.37 & 31 & 73 & 0.74 & 0.44 \\
\hline 2 & 73 & 0.92 & 0.28 & 12 & 73 & 0.82 & 0.39 & 22 & 73 & 0.75 & 0.43 & 32 & 73 & 0.84 & 0.37 \\
\hline 3 & 73 & 0.60 & 0.49 & 13 & 73 & 0.89 & 0.31 & 23 & 73 & 0.77 & 0.43 & 33 & 73 & 0.62 & 0.49 \\
\hline 4 & 73 & 0.88 & 0.33 & 14 & 73 & 0.89 & 0.31 & 24 & 73 & 0.82 & 0.39 & 34 & 73 & 0.55 & 0.50 \\
\hline 5 & 73 & 0.75 & 0.43 & 15 & 73 & 0.62 & 0.49 & 25 & 73 & 0.68 & 0.47 & 35 & 73 & 0.66 & 0.48 \\
\hline 6 & 73 & 0.78 & 0.42 & 16 & 73 & 0.15 & 0.36 & 26 & 73 & 0.82 & 0.56 & 36 & 73 & 0.70 & 0.46 \\
\hline 7 & 73 & 0.44 & 0.50 & 17 & 73 & 0.75 & 0.43 & 27 & 73 & 0.62 & 0.49 & 37 & 73 & 0.63 & 0.49 \\
\hline 8 & 73 & 0.10 & 0.30 & 18 & 73 & 0.44 & 0.50 & 28 & 73 & 0.82 & 0.39 & 38 & 73 & 0.33 & 0.47 \\
\hline 9 & 73 & 0.88 & 0.33 & 19 & 73 & 0.64 & 0.48 & 29 & 73 & 0.56 & 0.50 & 39 & 73 & 0.40 & 0.49 \\
\hline 10 & 73 & 0.27 & 0.45 & 20 & 73 & 0.64 & 0.48 & 30 & 73 & 0.84 & 0.37 & 40 & 73 & 0.26 & 0.44 \\
\hline
\end{tabular}

Taslak KTT ilk uygulamasında yer alan test maddelerinin analizinde, \%27'lik alt-üst grup ortalamaları farkına dayalı madde analizi yöntemi kullanılmıştır.

Madde güçlüğü ( $\left.p_{j}\right)$ 0-1 arasında değer almakta; 0’a yaklaştıkça madde zorlaşmakta, 1'e yaklaştıkça da kolaylaşmaktadır. Maddelerin güçlük düzeyleri ile ilgili olarak madde güçlük indeksi (pj); 0.00-0.19 arasında ise madde çok zor, 0.20-0.34 arasında ise madde zor, 0.35-0.64 arasında ise madde orta güçlükte, 0.65-0.79 arasında ise madde kolay, 0.80-1.00 arasında ise madde çok kolay olarak kabul edilir (Sözbilir, 2010).

Bir maddenin bilenle bilmeyeni ne derece ayırdığını gösteren madde ayırt ediciliği $(\mathrm{rj} \times)$ ise, -1 ile 1 arasında değişmekte olup, maddenin ayırt ediciliğinin 0'a yaklaşması ayırt ediciliğinin düşmesi, 1'e yaklaşması ayırt ediciliğinin artması anlamına gelmektedir (Gönen, Kocakaya \& Kocakaya, 2011). Ölçekten alınan toplam puanlara göre, en yüksek puandan en düşük puana doğru sıralandığında, üst grup ve alt-grup olan uç grupların, her bir maddeye verdikleri puan ortalamalarının karşılaştııılmasıdır (Tavşancıl, 2010).

Madde analizi sonuçlarında (Tablo 4), testte kalmasına karar verilecek maddelerin seçiminde madde ayırt edicilik indeksi (rjx) olarak; rj $x \leq 0.19$ ise madde kabul edilmez; 0.200.29 arasında ise madde düzeltilmeli; $0.30-0.39$ arasında ise iyi bir maddedir/kabul edilir; $0.40 \leq$ rjx ise çok iyi bir madde/ kabul edilir ölçütleri kullanılmıştır (Özçelik, 2010).

Tablo 4. Başarı testi birinci uygulama sonucu madde analizi tablosu

\begin{tabular}{|c|c|c|c|c|c|c|c|c|}
\hline Madde No & Gruplar & $\mathbf{A}$ & B & C & D & Boş & Cevap Sayısı & \\
\hline \multirow[t]{2}{*}{$1^{* *}$} & Üst Grup & - & - & $20^{*}$ & - & - & 20 & $\mathrm{P}_{\mathrm{j}}=0.93$ \\
\hline & Alt Grup & 1 & 1 & $17^{*}$ & 1 & - & 20 & $\mathrm{rj}_{\mathrm{x}}=0.15$ \\
\hline \multirow[t]{2}{*}{$2^{* *}$} & Üst Grup & - & - & - & $20^{*}$ & - & 20 & $\mathrm{P}_{\mathrm{j}}=0.95$ \\
\hline & Alt Grup & - & 1 & 1 & $18^{*}$ & - & 20 & $\mathrm{rj}_{\mathrm{x}}=0.10$ \\
\hline \multirow[t]{2}{*}{3} & Üst Grup & - & 1 & $15^{*}$ & 4 & - & 20 & $\mathrm{P}_{\mathrm{j}}=0.56$ \\
\hline & Alt Grup & 1 & 4 & $8 *$ & 5 & 2 & 20 & $\mathrm{rj}_{\mathrm{x}}=0.35$ \\
\hline \multirow[t]{2}{*}{4} & Üst Grup & $20^{*}$ & - & - & - & - & 20 & $\mathrm{P}_{\mathrm{j}}=0.80$ \\
\hline & Alt Grup & $12^{*}$ & 2 & 5 & - & 1 & 20 & $r_{x}=0.40$ \\
\hline \multirow[t]{2}{*}{5} & Üst Grup & 2 & $16^{*}$ & - & - & 2 & 20 & $\mathrm{P}_{\mathrm{j}}=0.65$ \\
\hline & Alt Grup & 2 & $10^{*}$ & 2 & 3 & 3 & 20 & $\mathrm{rj}_{\mathrm{x}}=0.30$ \\
\hline
\end{tabular}


Aymen-Peker \& Taş

\begin{tabular}{|c|c|c|c|c|c|c|c|c|}
\hline Madde No & Gruplar & A & B & $\mathrm{C}$ & D & Boş & Cevap Sayısı & \\
\hline \multirow[t]{2}{*}{6} & Üst Grup & $18^{*}$ & - & 1 & 1 & - & 20 & $P_{\mathrm{j}}=0.75$ \\
\hline & Alt Grup & $12^{*}$ & 1 & 4 & 1 & 2 & 20 & $\mathrm{rj}_{x}=0.30$ \\
\hline \multirow[t]{2}{*}{7} & Üst Grup & - & $16^{*}$ & 4 & - & - & 20 & $P_{j}=0.53$ \\
\hline & Alt Grup & - & $5^{*}$ & 14 & 1 & - & 20 & $\mathrm{rj}_{\mathrm{x}}=0.55$ \\
\hline \multirow[t]{2}{*}{8} & Üst Grup & - & 5 & 3 & $11^{*}$ & 1 & 20 & $P_{j}=0.38$ \\
\hline & Alt Grup & 4 & 5 & 4 & $4^{*}$ & 3 & 20 & $\mathrm{rj}_{\mathrm{x}}=0.35$ \\
\hline \multirow[t]{2}{*}{$9^{* *}$} & Üst Grup & - & $20^{*}$ & - & - & - & 20 & $P_{j}=0.93$ \\
\hline & Alt Grup & - & $17^{*}$ & - & 2 & 1 & 20 & $r j_{x}=0.15$ \\
\hline \multirow[t]{2}{*}{$10^{* *}$} & Üst Grup & $10^{*}$ & 8 & 2 & - & - & 20 & $\mathrm{P}_{\mathrm{j}}=0.43$ \\
\hline & Alt Grup & $7^{*}$ & 8 & 4 & 1 & 1 & 20 & $r j_{x}=0.15$ \\
\hline \multirow[t]{2}{*}{11} & Üst Grup & - & - & $20^{*}$ & - & - & 20 & $\mathrm{P}_{\mathrm{j}}=0.83$ \\
\hline & Alt Grup & 1 & 1 & $13^{*}$ & 3 & 2 & 20 & $\mathrm{rj}_{\mathrm{x}}=0.35$ \\
\hline \multirow[t]{2}{*}{12} & Üst Grup & - & - & $20^{*}$ & - & - & 20 & $P_{j}=0.83$ \\
\hline & Alt Grup & - & 2 & $13^{*}$ & 2 & 3 & 20 & $\mathrm{rj}_{\mathrm{x}}=0.35$ \\
\hline \multirow[t]{2}{*}{13} & Üst Grup & 1 & - & $19^{*}$ & - & - & 20 & $P_{j}=0.78$ \\
\hline & Alt Grup & 3 & 3 & $12^{*}$ & 1 & 1 & 20 & $\mathrm{rj}_{\mathrm{x}}=0.35$ \\
\hline \multirow[t]{2}{*}{14} & Üst Grup & - & - & $20^{*}$ & - & - & 20 & $P_{j}=0.88$ \\
\hline & Alt Grup & 2 & 3 & $13^{*}$ & - & 2 & 20 & $\mathrm{rj}_{\mathrm{x}}=0.35$ \\
\hline \multirow[t]{2}{*}{15} & Üst Grup & - & $16^{*}$ & 1 & 2 & 1 & 20 & $P_{\mathrm{j}}=0.58$ \\
\hline & Alt Grup & 1 & $7^{*}$ & 2 & 9 & 1 & 20 & $\mathrm{rj}_{x}=0.45$ \\
\hline $16^{* *}$ & Üst Grup & 8 & - & $6^{*}$ & 3 & 3 & 20 & $\mathrm{P}_{\mathrm{j}}=0.18$ \\
\hline & Alt Grup & 12 & 1 & $1^{*}$ & 2 & 4 & 20 & $\mathrm{rj}_{x}=0.25$ \\
\hline 17 & Üst Grup & - & - & - & $18^{*}$ & 2 & 20 & $P_{j}=0.68$ \\
\hline & Alt Grup & 3 & 1 & 4 & $9^{*}$ & 3 & 20 & $\mathrm{rj}_{\mathrm{x}}=0.45$ \\
\hline 18 & Üst Grup & $14^{*}$ & 3 & - & 2 & 1 & 20 & $P_{j}=0.53$ \\
\hline & Alt Grup & $7^{*}$ & 4 & 5 & 2 & 2 & 20 & $\mathrm{rj}_{\mathrm{x}}=0.35$ \\
\hline 19 & Üst Grup & - & 2 & $17^{*}$ & 1 & - & 20 & $P_{\mathrm{j}}=0.60$ \\
\hline & Alt Grup & 4 & 2 & $7^{*}$ & 7 & - & 20 & $\mathrm{rj}_{\mathrm{x}}=0.50$ \\
\hline 20 & Üst Grup & - & 1 & $18^{*}$ & - & 1 & 20 & $\mathrm{P}_{\mathrm{j}}=0.63$ \\
\hline & Alt Grup & 1 & 3 & $7^{*}$ & 5 & 4 & 20 & $\mathrm{rjx}=0.55$ \\
\hline 21 & Üst Grup & - & - & 1 & $19^{*}$ & - & 20 & $P_{\mathrm{j}}=0.78$ \\
\hline & Alt Grup & 2 & 3 & 2 & $12^{*}$ & 1 & 20 & $\mathrm{rj}_{\mathrm{x}}=0.35$ \\
\hline 22 & Üst Grup & - & $17^{*}$ & - & 1 & 2 & 20 & $P_{j}=0.68$ \\
\hline & Alt Grup & 3 & $10^{*}$ & 2 & 3 & 2 & 20 & $\mathrm{rjx}=0.35$ \\
\hline 23 & Üst Grup & - & $20^{*}$ & - & - & - & 20 & $P_{j}=0.70$ \\
\hline & Alt Grup & 4 & $8^{*}$ & 1 & 4 & 3 & 20 & $\mathrm{rj}_{\mathrm{x}}=0.60$ \\
\hline $24^{* *}$ & Üst Grup & - & 1 & - & $19^{*}$ & - & 20 & $\mathrm{P}_{\mathrm{j}}=0.83$ \\
\hline & Alt Grup & - & 3 & 2 & $14^{*}$ & 1 & 20 & $\mathrm{rj}_{\mathrm{x}}=0.25$ \\
\hline 25 & Üst Grup & - & $18^{*}$ & - & 2 & - & 20 & $\mathrm{P}_{\mathrm{j}}=0.53$ \\
\hline & Alt Grup & 3 & $3^{*}$ & 3 & 7 & 4 & 20 & $\mathrm{rj} \mathrm{j}_{\mathrm{x}}=0.75$ \\
\hline 26 & Üst Grup & - & - & - & $20^{*}$ & - & 20 & $\mathrm{P}_{\mathrm{j}}=0.68$ \\
\hline & Alt Grup & 4 & 5 & 2 & $7^{*}$ & 2 & 20 & $\mathrm{rj}_{\mathrm{x}}=0.65$ \\
\hline 27 & Üst Grup & - & $19^{*}$ & - & 1 & - & 20 & $P_{j}=0.58$ \\
\hline & Alt Grup & 2 & $4^{*}$ & 7 & 4 & 3 & 20 & $\mathrm{rj}_{\mathrm{x}}=0.75$ \\
\hline 28 & Üst Grup & - & $20^{*}$ & - & - & - & 20 & $P_{j}=0.73$ \\
\hline & Alt Grup & 3 & $9^{*}$ & 3 & 4 & 1 & 20 & $\mathrm{rj}_{\mathrm{x}}=0.55$ \\
\hline $29^{* *}$ & Üst Grup & - & - & 7 & $12^{*}$ & 1 & 20 & $P_{\mathrm{j}}=0.50$ \\
\hline & Alt Grup & 2 & 3 & 4 & $8^{*}$ & 3 & 20 & $\mathrm{rj} \mathrm{j}_{\mathrm{x}}=0.20$ \\
\hline $30^{* *}$ & Üst Grup & 1 & $17^{*}$ & 2 & - & - & 20 & $\mathrm{P}_{\mathrm{j}}=0.80$ \\
\hline & Alt Grup & 2 & $15^{*}$ & 1 & 2 & - & 20 & $\mathrm{rj} x=0.10$ \\
\hline 31 & Üst Grup & 1 & 1 & - & $18^{*}$ & - & 20 & $P_{j}=0.68$ \\
\hline & Alt Grup & 3 & 2 & 6 & $9^{*}$ & - & 20 & $\mathrm{rj}_{\mathrm{x}}=0.45$ \\
\hline 32 & Üst Grup & - & - & $18^{*}$ & 2 & - & 20 & $P_{j}=0.73$ \\
\hline & Alt Grup & 5 & - & $11^{*}$ & 3 & 1 & 20 & $\mathrm{rj}_{\mathrm{x}}=0.35$ \\
\hline 33 & Üst Grup & - & 3 & $17^{*}$ & - & - & 20 & $P_{j}=0.60$ \\
\hline & Alt Grup & 3 & 8 & $7^{*}$ & - & 2 & 20 & $\mathrm{rj}_{\mathrm{x}}=0.50$ \\
\hline $34^{* *}$ & Üst Grup & - & 5 & $15^{*}$ & - & - & 20 & $P_{j}=0.65$ \\
\hline & Alt Grup & 2 & 6 & $11^{*}$ & 1 & - & 20 & $r j_{x}=0.20$ \\
\hline 35 & Üst Grup & - & - & $19^{*}$ & - & 1 & 20 & $\mathrm{P}_{\mathrm{j}}=0.63$ \\
\hline & Alt Grup & 4 & 5 & $6^{*}$ & 4 & 1 & 20 & $\mathrm{rj}_{\mathrm{x}}=0.65$ \\
\hline 36 & Üst Grup & $19^{*}$ & - & - & - & 1 & 20 & $P_{j}=0.68$ \\
\hline & Alt Grup & $8^{*}$ & 3 & 3 & 4 & 2 & 20 & $\mathrm{rj}_{\mathrm{x}}=0.55$ \\
\hline 37 & Üst Grup & - & - & $19^{*}$ & 1 & - & 20 & $P_{j}=0.68$ \\
\hline & Alt Grup & 2 & 7 & $8^{*}$ & 3 & - & 20 & $\mathrm{rj}_{\mathrm{x}}=0.55$ \\
\hline 38 & Üst Grup & - & 2 & 9 & $9^{*}$ & - & 20 & $P_{j}=0.23$ \\
\hline & Alt Grup & 3 & 6 & 6 & $2^{*}$ & 3 & 20 & $\mathrm{rj}_{\mathrm{x}}=0.35$ \\
\hline 39 & Üst Grup & $16^{*}$ & - & 3 & 1 & - & 20 & $P_{\mathrm{j}}=0.43$ \\
\hline & Alt Grup & $1^{*}$ & 3 & 9 & 6 & 1 & 20 & $\mathrm{rj}_{x}=0.75$ \\
\hline $40^{* *}$ & Üst Grup & 12 & - & - & $8^{*}$ & - & 20 & $\mathrm{P}_{\mathrm{j}}=0.33$ \\
\hline
\end{tabular}


Aymen-Peker \& Tas

\begin{tabular}{lllllllll}
\hline Madde No & Gruplar & A & B & C & D & Boş & Cevap Sayısı & \\
\hline & Alt Grup & 6 & 4 & 5 & $5^{*}$ & - & 20 & rjx $=\mathbf{0 . 1 5}$
\end{tabular}

*Test maddesinin doğru cevap seçeneğidir.

** Madde analizi sonucu testten çıkarılan maddeler

$\mathrm{P}_{\mathrm{j}}=$ Maddenin güçlük indeksi: ((Maddeyi üst grupta doğru cevaplayanlar + Maddeyi alt grupta doğru cevaplayanlar) / Toplam cevaplayan)

rje Maddenin ayırt edicilik gücü: ((Maddeyi üst grupta doğru cevaplayanlar-Maddeyi alt grupta doğru cevaplayanlar) / Üst ya da alt gruptan herhangi birisinin eleman sayısı)

Uygulamada veriler Microsoft Excel programına girilmiş, maddelerin güçlük dereceleri, standart sapmaları ve ayırıcılık dereceleri hesaplanarak, çok kolay ve çok zor olarak belirlenen sorular testten çıkarılmıştır. Ayırıcılık dereceleri 0.20 ve altında olan maddeler $(1,2,9,10,29,30,34$ ve 40$)$ ile ayırıcılık derecesi 0.25 olmasına rağmen çok kolay ve çok zor madde olarak belirlenen 16. ve 24. sorular testten çıkarılmıştır (Tablo 5; Tablo 6).

Tablo 5. Üst ve alt grup öğrencilerinin doğru sayısına göre başarı test madde analizi

\begin{tabular}{|c|c|c|c|c|c|c|c|c|c|c|c|c|c|c|c|}
\hline$\frac{\pi}{\pi}$ & dü & da & pj & 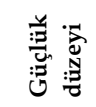 & rjx & Sonuç & 焉 & $\frac{\frac{0}{\tau}}{\frac{\pi}{\tau}}$ & dü & da & pj & 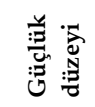 & rjx & Sonuç & 䒠 \\
\hline 1 & 20 & 17 & 0.93 & ÇK & 0.15 & Çık & - & 21 & 19 & 12 & 0.78 & $\mathrm{~K}$ & 0.35 & İyi & $\sqrt{ }$ \\
\hline 2 & 20 & 18 & 0.95 & ÇK & 0.10 & Çık & - & 22 & 17 & 10 & 0.68 & K & 0.35 & İyi & $\sqrt{ }$ \\
\hline 3 & 15 & 8 & 0.56 & $\mathrm{O}$ & 0.35 & $\dot{I}$ & $\sqrt{ }$ & 23 & 20 & 8 & 0.70 & $\mathrm{~K}$ & 0.60 & Çİ & $\sqrt{ }$ \\
\hline 4 & 20 & 12 & 0.80 & ÇK & 0.40 & Ç̇ं & $\sqrt{ }$ & 24 & 19 & 14 & 0.83 & ÇK & 0.25 & Düz & - \\
\hline 5 & 16 & 10 & 0.65 & $\mathrm{~K}$ & 0.30 & İyi & $\sqrt{ }$ & 25 & 18 & 3 & 0.53 & $\mathrm{O}$ & 0.75 & Çİ & $\sqrt{ }$ \\
\hline 6 & 18 & 12 & 0.75 & K & 0.30 & İyi & $\sqrt{ }$ & 26 & 20 & 7 & 0.68 & $\mathrm{~K}$ & 0.65 & Çì & $\sqrt{ }$ \\
\hline 7 & 16 & 5 & 0.53 & $\mathrm{O}$ & 0.55 & Çİ & $\sqrt{ }$ & 27 & 19 & 4 & 0.58 & $\mathrm{O}$ & 0.75 & Ç்َ & $\sqrt{ }$ \\
\hline 8 & 11 & 4 & 0.38 & $\mathrm{O}$ & 0.35 & İyi & $\sqrt{ }$ & 28 & 20 & 9 & 0.73 & $\mathrm{~K}$ & 0.55 & ç்َ & $\sqrt{ }$ \\
\hline 9 & 20 & 17 & 0.93 & ÇK & 0.15 & Çık & - & 29 & 12 & 9 & 0.53 & $\mathrm{O}$ & 0.15 & Çık & - \\
\hline 10 & 10 & 7 & 0.43 & $\mathrm{O}$ & 0.15 & Çık & - & 30 & 17 & 15 & 0.80 & ÇK & 0.10 & Çık & - \\
\hline 11 & 20 & 13 & 0.83 & ÇK & 0.35 & İyi & $\sqrt{ }$ & 31 & 18 & 9 & 0.68 & $\mathrm{~K}$ & 0.45 & Çं & $\sqrt{ }$ \\
\hline 12 & 20 & 13 & 0.83 & ÇK & 0.35 & İyi & $\sqrt{ }$ & 32 & 18 & 11 & 0.73 & $\mathrm{~K}$ & 0.35 & İyi & $\sqrt{ }$ \\
\hline 13 & 19 & 12 & 0.78 & $\mathrm{~K}$ & 0.35 & İyi & $\sqrt{ }$ & 33 & 17 & 7 & 0.60 & $\mathrm{O}$ & 0.50 & ÇI் & $\sqrt{ }$ \\
\hline 14 & 20 & 13 & 0.83 & ÇK & 0.35 & İyi & $\sqrt{ }$ & 34 & 15 & 11 & 0.65 & $\mathrm{~K}$ & 0.20 & Düz & - \\
\hline 15 & 16 & 7 & 0.58 & $\mathrm{O}$ & 0.45 & Çİ & $\sqrt{ }$ & 35 & 19 & 6 & 0.63 & $\mathrm{O}$ & 0.65 & Çİ & $\sqrt{ }$ \\
\hline 16 & 6 & 1 & 0.18 & ÇZ & 0.25 & Düz & - & 36 & 19 & 8 & 0.68 & $\mathrm{~K}$ & 0.55 & Ç்َ & $\sqrt{ }$ \\
\hline 17 & 18 & 9 & 0.68 & ÇK & 0.45 & Çİ & $\sqrt{ }$ & 37 & 19 & 8 & 0.68 & $\mathrm{~K}$ & 0.55 & Çİ & $\sqrt{ }$ \\
\hline 18 & 14 & 7 & 0.53 & $\mathrm{O}$ & 0.35 & İyi & $\sqrt{ }$ & 38 & 9 & 2 & 0.23 & $\mathrm{Z}$ & 0.35 & İyi & $\sqrt{ }$ \\
\hline 19 & 17 & 7 & 0.60 & $\mathrm{O}$ & 0.50 & Çi் & $\sqrt{ }$ & 39 & 16 & 1 & 0.43 & $\mathrm{O}$ & 0.75 & Ç்َ & $\sqrt{ }$ \\
\hline 20 & 18 & 7 & 0.63 & $\mathrm{O}$ & 0.55 & Ç்َ & $\sqrt{ }$ & 40 & 8 & 5 & 0.33 & Z & 0.15 & Çık & - \\
\hline
\end{tabular}

ÇK: Çok Kolay, K: Kolay, O: Orta, Z: Zor, ÇZ: Çok zor, Çİ: Çok iyi, İ: İyi, Çık: Çıkarılmalı, Düz:

Düzeltilmeli

Veriler SPSS programına aktarılmış, başarı testinin toplamından alınan puan (sürekli değişken) ile testin her maddesinden alınan puan arasındaki ilişki çift serili korelasyon şeklinde hesaplanmıştır. Çift serili korelasyon katsayısı, sürekli bir değişken ile gerçekte sürekli, ancak yapay olarak iki kategorili süreksiz bir duruma getirilen bir değişken arasındaki ilişki miktarı hesaplarken kullanılmaktadır (Büyüköztürk, Çokluk \& Köklü, 2010).

Cevaplayıcıların ölçme aracından aldığı toplam puan ile her bir maddeden aldığ puan arasındaki ilişkiyi madde toplam korelasyonu açıklar. Korelasyonun pozitif ve yüksek olması, testin iç tutarlılığının yüksek olduğunu ve ölçek maddelerinin benzer davranışları 
örneklediğini gösterir (Büyüköztürk, 2010). Herhangi bir maddenin, toplam puan ile korelasyonu düşük ise, o maddenin diğer maddelerden farklı bir özelliği ölçtüğü şeklinde ilişki yorumlanır. Madde toplam korelasyonunun negatif olmaması ve en az 0.20 olması gerekmektedir. Negatif değer olması ölçeğin toplanabilirlik özelliğini bozmaktadır.

Tablo 6. Birinci uygulamada yer alan maddelerin çift serili korelasyon katsayısı değerleri

\begin{tabular}{|c|c|c|c|c|c|c|c|c|}
\hline $\begin{array}{l}\text { Madde } \\
\text { No }\end{array}$ & $\mathbf{N}$ & $\mathbf{p}$ & $q$ & $\overline{\mathbf{Y}} \mathbf{p}$ & $\overline{\mathbf{Y}} \mathbf{q}$ & SS & $\mathrm{pq} / \mathrm{y}$ & $\mathbf{r}_{\varsigma}$ \\
\hline 1 & 73 & 0.96 & 0.04 & 26.82 & 18.00 & 0.20 & 0.45 & 0.42 \\
\hline $2^{*}$ & 73 & 0.92 & 0.08 & 26.76 & 23.17 & 0.28 & 0.50 & 0.19 \\
\hline 3 & 73 & 0.60 & 0.40 & 28.11 & 23.97 & 0.49 & 0.62 & 0.30 \\
\hline 4 & 73 & 0.88 & 0.12 & 27.86 & 16.56 & 0.33 & 0.53 & 0.64 \\
\hline 5 & 73 & 0.75 & 0.25 & 27.71 & 22.67 & 0.43 & 0.59 & 0.32 \\
\hline 6 & 73 & 0.78 & 0.22 & 27.67 & 22.19 & 0.42 & 0.58 & 0.34 \\
\hline $7^{*}$ & 73 & 0.44 & 0.56 & 28.75 & 24.68 & 0.50 & 0.63 & 0.27 \\
\hline $8^{*}$ & 73 & 0.10 & 0.90 & 31.00 & 25.98 & 0.30 & 0.51 & 0.27 \\
\hline $9^{*}$ & 73 & 0.88 & 0.12 & 26.88 & 23.56 & 0.33 & 0.53 & 0.19 \\
\hline $10^{*}$ & 73 & 0.27 & 0.73 & 28.20 & 25.81 & 0.45 & 0.60 & 0.15 \\
\hline $11^{*}$ & 73 & 0.85 & 0.15 & 27.61 & 20.00 & 0.36 & 0.55 & 0.44 \\
\hline 12 & 73 & 0.82 & 0.18 & 27.72 & 20.69 & 0.39 & 0.57 & 0.43 \\
\hline 13 & 73 & 0.89 & 0.11 & 27.43 & 18.63 & 0.31 & 0.52 & 0.49 \\
\hline 14 & 73 & 0.89 & 0.11 & 27.18 & 20.63 & 0.31 & 0.52 & 0.36 \\
\hline 15 & 73 & 0.62 & 0.38 & 28.22 & 23.64 & 0.49 & 0.62 & 0.30 \\
\hline $16^{*}$ & 73 & 0.15 & 0.85 & 29.82 & 25.87 & 0.36 & 0.55 & 0.23 \\
\hline 17 & 73 & 0.75 & 0.25 & 31.20 & 24.00 & 0.43 & 0.59 & 0.45 \\
\hline $18^{*}$ & 73 & 0.44 & 0.56 & 27.84 & 25.39 & 0.50 & 0.63 & 0.16 \\
\hline 19 & 73 & 0.64 & 0.36 & 28.45 & 22.88 & 0.48 & 0.62 & 0.37 \\
\hline 20 & 73 & 0.64 & 0.36 & 28.64 & 22.54 & 0.48 & 0.62 & 0.40 \\
\hline 21 & 73 & 0.84 & 0.16 & 27.84 & 19.50 & 0.37 & 0.55 & 0.49 \\
\hline 22 & 73 & 0.75 & 0.25 & 28.11 & 21.44 & 0.43 & 0.59 & 0.42 \\
\hline 23 & 73 & 0.77 & 0.23 & 28.79 & 18.82 & 0.43 & 0.58 & 0.61 \\
\hline $24^{*}$ & 73 & 0.82 & 0.18 & 27.20 & 23.08 & 0.39 & 0.56 & 0.25 \\
\hline 25 & 73 & 0.69 & 0.31 & 29.38 & 20.13 & 0.47 & 0.61 & 0.60 \\
\hline 26 & 73 & 0.78 & 0.22 & 28.74 & 18.38 & 0.56 & 0.58 & 0.64 \\
\hline 27 & 73 & 0.62 & 0.38 & 29.58 & 21.46 & 0.49 & 0.62 & 0.54 \\
\hline 28 & 73 & 0.82 & 0.18 & 28.05 & 19.15 & 0.39 & 0.56 & 0.53 \\
\hline $29^{*}$ & 73 & 0.56 & 0.44 & 28.07 & 24.41 & 0.50 & 0.63 & 0.25 \\
\hline $30^{*}$ & 73 & 0.84 & 0.16 & 26.98 & 23.83 & 0.37 & 0.55 & 0.18 \\
\hline 31 & 73 & 0.74 & 0.26 & 28.24 & 21.42 & 0.44 & 0.59 & 0.43 \\
\hline 32 & 73 & 0.84 & 0.16 & 27.38 & 21.83 & 0.37 & 0.55 & 0.32 \\
\hline 33 & 73 & 0.62 & 0.38 & 28.51 & 23.18 & 0.49 & 0.62 & 0.35 \\
\hline $34^{*}$ & 73 & 0.55 & 0.45 & 28.28 & 24.27 & 0.50 & 0.63 & 0.27 \\
\hline 35 & 73 & 0.66 & 0.34 & 29.15 & 21.32 & 0.48 & 0.61 & 0.51 \\
\hline 36 & 73 & 0.70 & 0.30 & 28.29 & 21.55 & 0.46 & 0.60 & 0.43 \\
\hline 37 & 73 & 0.63 & 0.37 & 29.07 & 22.04 & 0.49 & 0.62 & 0.46 \\
\hline 38 & 73 & 0.33 & 0.67 & 29.42 & 25.02 & 0.47 & 0.61 & 0.30 \\
\hline 39 & 73 & 0.40 & 0.60 & 31.24 & 23.32 & 0.49 & 0.62 & 0.52 \\
\hline $40^{*}$ & 73 & 0.26 & 0.74 & 27.53 & 26.09 & 0.44 & 0.59 & 0.09 \\
\hline
\end{tabular}

Taslak başarı testinde yer alan her bir maddenin çift serili korelasyon katsayı değeri hesaplandığında $2,7,8,9,10,16,18,24,29,30,34$ ve 40 . maddelerin korelasyon katsayı değerleri 0.30'un altındadır (Tablo 6). Bu soru maddelerinden 2, 9, 10,16, 24, 29, 30, 34 ve 40 daha önce yapılan madde güçlük ve ayırt edicilik hesaplamasında düşük çıkarak elenen maddelerdir. 2, 8 ve 18. maddelerin korelasyon değeri 0.20 üzerinde olduğu için taslak test 
içerisinde kalmasına karar verilmiştir. Maddeler arasındaki korelasyonun yüksek olması, maddelerin homojen olduğunu ve dolayısıyla güvenirliğinde yüksek olduğunu göstermektedir (Tavşanc1l, 2010).

Madde analizi sonucunda 30 maddeye düşen testin KR-20 güvenirlik testi sonucu Formül-3 ile hesaplanıp, 0.86 olarak belirlenmiştir. Bir ölçme aracının güvenilir kabul edilebilmesi için KR-20 güvenirlik katsayısının 0.70 ve üzerinde olması beklenmektedir (Özçelik, 2010). Bu sebeple madde analizi gerçekleştirilen testin güvenilir olduğu kabul edilmiştir.

$$
K R 20=\frac{K}{K-1} \times\left(1-\frac{\Sigma p q}{S_{X^{2}}}\right)
$$

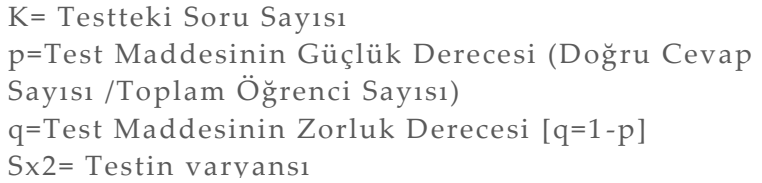

Geliştirilen birinci aşama başarı testi madde elemesi tamamlandıktan sonra, test maddelerinin ünitede yer alan konu ve kazanımlara göre dağılımı Tablo 7' de yer almaktadır.

Tablo 7. Nihai birinci aşama başarı testinde yer alan soru maddelerinin konulara ve kazanımlara göre dağılımı

\begin{tabular}{lllc}
\hline Konular & Kazanımlar & Madde Numarası & Madde Sayısı \\
\hline Canlıları Tanıyalım & 5.5 .1 .1$. & $1,2,3,4,5,6,7,9,11,18,27,28,29,30$ & 14 \\
İnsan ve Çevre İlişkisi & 5.5 .2 .1$. & $8,12,13,15,16,19,20,21,23,24,25,26$ & 12 \\
& 5.5 .2 .2$. & $10,14,17,22$ & 4 \\
\hline
\end{tabular}

30 sorudan oluşan nihai test pilot uygulamada 62 beşinci sınıf öğrencisine uygulanmıştır. Başarı testinin, ikinci uygulamasındaki test maddelerinin aritmetik ortalama ve standart sapma değerleri Tablo 8 'de verilmiştir.

Tablo 8. Taslak başarı testi ikinci uygulamasındaki soruların aritmetik ortalama ve standart sapma değerleri

\begin{tabular}{cccccccccccc}
\hline $\begin{array}{c}\text { Madde } \\
\text { No }\end{array}$ & $\mathbf{N}$ & $\overline{\boldsymbol{x}}$ & SS & $\begin{array}{c}\text { Madde } \\
\text { No }\end{array}$ & $\mathbf{N}$ & $\overline{\boldsymbol{x}}$ & SS & $\begin{array}{c}\text { Madde } \\
\text { No }\end{array}$ & $\mathbf{N}$ & $\overline{\boldsymbol{x}}$ & SS \\
\hline $\mathbf{1}$ & 62 & 0.90 & 0.30 & $\mathbf{1 1}$ & 62 & 0.73 & 0.45 & $\mathbf{2 1}$ & 62 & 0.37 & 0.49 \\
$\mathbf{2}$ & 62 & 0.79 & 0.41 & $\mathbf{1 2}$ & 62 & 0.56 & 0.50 & $\mathbf{2 2}$ & 62 & 0.45 & 0.50 \\
$\mathbf{3}$ & 62 & 0.69 & 0.46 & $\mathbf{1 3}$ & 62 & 0.68 & 0.47 & $\mathbf{2 3}$ & 62 & 0.44 & 0.50 \\
$\mathbf{4}$ & 62 & 0.73 & 0.45 & $\mathbf{1 4}$ & 62 & 0.58 & 0.50 & $\mathbf{2 4}$ & 62 & 0.47 & 0.50 \\
$\mathbf{5}$ & 62 & 0.65 & 0.48 & $\mathbf{1 5}$ & 62 & 0.66 & 0.48 & $\mathbf{2 5}$ & 62 & 0.39 & 0.49 \\
$\mathbf{6}$ & 62 & 0.68 & 0.47 & $\mathbf{1 6}$ & 62 & 0.60 & 0.49 & $\mathbf{2 6}$ & 62 & 0.37 & 0.49 \\
$\mathbf{7}$ & 62 & 0.74 & 0.44 & $\mathbf{1 7}$ & 62 & 0.65 & 0.48 & $\mathbf{2 7}$ & 62 & 0.24 & 0.43 \\
$\mathbf{8}$ & 62 & 0.48 & 0.50 & $\mathbf{1 8}$ & 62 & 0.56 & 0.50 & $\mathbf{2 8}$ & 62 & 0.66 & 0.48 \\
$\mathbf{9}$ & 62 & 0.53 & 0.50 & $\mathbf{1 9}$ & 62 & 0.50 & 0.50 & $\mathbf{2 9}$ & 62 & 0.32 & 0.47 \\
$\mathbf{1 0}$ & 62 & 0.55 & 0.50 & $\mathbf{2 0}$ & 62 & 0.52 & 0.50 & $\mathbf{3 0}$ & 62 & 0.44 & 0.50 \\
\hline
\end{tabular}

Birinci uygulamada olduğu gibi elde edilen test puanlarına \%27'lik alt-üst grup ortalamaları farkına dayalı madde analizi uygulanmıştır. (Tablo 9; Tablo 10). 
Tablo 9. Başarı testi ikinci uygulama sonucu madde analizi tablosu

\begin{tabular}{|c|c|c|c|c|c|c|c|c|}
\hline Madde No & Gruplar & A & B & $\mathrm{C}$ & D & Boş & Cevap Sayısı & \\
\hline \multirow[t]{2}{*}{1} & Üst Grup & $17^{*}$ & - & - & - & - & 17 & $\mathrm{P}_{\mathrm{j}}=0.85$ \\
\hline & Alt Grup & $12^{*}$ & - & 4 & - & 1 & 17 & $\mathrm{rj} x=0.29$ \\
\hline \multirow[t]{2}{*}{2} & Üst Grup & - & 1 & $16^{*}$ & - & - & 17 & $\mathrm{P}_{\mathrm{j}}=0.79$ \\
\hline & Alt Grup & 2 & 1 & $11^{*}$ & 2 & 1 & 17 & $\mathrm{rj} x=0.29$ \\
\hline \multirow[t]{2}{*}{3} & Üst Grup & - & $16^{*}$ & 1 & - & - & 17 & $\mathrm{P}_{\mathrm{j}}=0.65$ \\
\hline & Alt Grup & - & $6^{*}$ & 5 & 5 & 1 & 17 & $\mathrm{rj} x=0.59$ \\
\hline \multirow[t]{2}{*}{4} & Üst Grup & $17^{*}$ & - & - & - & - & 17 & $\mathrm{P}_{\mathrm{j}}=0.68$ \\
\hline & Alt Grup & $6^{*}$ & 5 & 3 & 2 & 1 & 17 & $\mathrm{rj} x=0.65$ \\
\hline \multirow[t]{2}{*}{5} & Üst Grup & 1 & 1 & $15^{*}$ & - & - & 17 & $\mathrm{P}_{\mathrm{j}}=0.68$ \\
\hline & Alt Grup & - & 3 & $8^{*}$ & 5 & 1 & 17 & $\mathrm{rj} x=0.41$ \\
\hline \multirow[t]{2}{*}{6} & Üst Grup & 3 & - & $14^{*}$ & - & - & 17 & $\mathrm{P}_{\mathrm{j}}=0.62$ \\
\hline & Alt Grup & 5 & 2 & $7^{*}$ & 2 & 1 & 17 & $r j x=0.41$ \\
\hline \multirow[t]{2}{*}{7} & Üst Grup & - & 1 & $16^{*}$ & - & - & 17 & $P_{j}=0.62$ \\
\hline & Alt Grup & 1 & 6 & $5^{*}$ & 4 & 1 & 17 & $\mathrm{rj} x=0.65$ \\
\hline \multirow[t]{2}{*}{8} & Üst Grup & - & - & $16^{*}$ & 1 & - & 17 & $\mathrm{P}_{\mathrm{j}}=0.53$ \\
\hline & Alt Grup & 5 & 4 & $2^{*}$ & 5 & 1 & 17 & $\mathrm{rj} x=0.82$ \\
\hline \multirow[t]{2}{*}{9} & Üst Grup & - & $17^{*}$ & - & - & - & 17 & $\mathrm{P}_{\mathrm{j}}=0.59$ \\
\hline & Alt Grup & 2 & $3^{*}$ & 2 & 9 & 1 & 17 & $\mathrm{rj} x=0.82$ \\
\hline \multirow[t]{2}{*}{10} & Üst Grup & - & 1 & $14^{*}$ & 2 & - & 17 & $\mathrm{P}_{\mathrm{j}}=0.56$ \\
\hline & Alt Grup & 7 & - & $5^{*}$ & 4 & 1 & 17 & $\mathrm{rj} x=0.53$ \\
\hline \multirow[t]{2}{*}{11} & Üst Grup & 3 & 2 & 5 & $7^{*}$ & - & 17 & $\mathrm{P}_{\mathrm{j}}=0.38$ \\
\hline & Alt Grup & 4 & 2 & 4 & $6^{*}$ & 1 & 17 & $\mathrm{rj} x=0.06$ \\
\hline \multirow[t]{2}{*}{12} & Üst Grup & - & 1 & - & $15^{*}$ & 1 & 17 & $\mathrm{P}_{\mathrm{j}}=0.59$ \\
\hline & Alt Grup & 4 & 3 & 4 & $5^{*}$ & 1 & 17 & $\mathrm{rj} x=0.59$ \\
\hline \multirow[t]{2}{*}{13} & Üst Grup & - & $16^{*}$ & 1 & - & - & 17 & $\mathrm{P}_{\mathrm{j}}=0.76$ \\
\hline & Alt Grup & 4 & $10^{*}$ & - & 2 & 1 & 17 & $\mathrm{rj} x=0.35$ \\
\hline \multirow[t]{2}{*}{14} & Üst Grup & - & 1 & $16^{*}$ & - & - & 17 & $\mathrm{P}_{\mathrm{j}}=0.59$ \\
\hline & Alt Grup & 6 & 4 & $4^{*}$ & 2 & 1 & 17 & $\mathrm{rj} x=0.71$ \\
\hline 15 & Üst Grup & - & - & 1 & $16^{*}$ & - & 17 & $\mathrm{P}_{\mathrm{j}}=0.62$ \\
\hline & Alt Grup & 4 & 1 & 6 & $5^{*}$ & 1 & 17 & $r j x=0.65$ \\
\hline 16 & Üst Grup & - & $16^{*}$ & - & - & 1 & 17 & $\mathrm{P}_{\mathrm{j}}=0.71$ \\
\hline & Alt Grup & 2 & $8^{*}$ & 3 & 3 & 1 & 17 & $\mathrm{rj} x=0.47$ \\
\hline 17 & Üst Grup & - & $16^{*}$ & 1 & - & - & 17 & $\mathrm{P}_{\mathrm{j}}=0.56$ \\
\hline & Alt Grup & 5 & $3^{*}$ & 6 & 2 & 1 & 17 & $\mathrm{rj} x=0.76$ \\
\hline 18 & Üst Grup & - & $16^{*}$ & - & - & 1 & 17 & $\mathrm{P}_{\mathrm{j}}=0.53$ \\
\hline & Alt Grup & 8 & $2^{*}$ & - & 6 & 1 & 17 & $\mathrm{rj} x=0.82$ \\
\hline 19 & Üst Grup & 1 & $16^{*}$ & - & - & - & 17 & $\mathrm{P}_{\mathrm{j}}=0.50$ \\
\hline & Alt Grup & 8 & $1^{*}$ & 1 & 6 & 1 & 17 & $\mathrm{rj} x=0.88$ \\
\hline 20 & Üst Grup & - & - & $15^{*}$ & 1 & - & 17 & $P_{j}=0.56$ \\
\hline & Alt Grup & 2 & 3 & $4^{*}$ & 7 & 1 & 17 & rjx $=0.65$ \\
\hline 21 & Üst Grup & - & - & $17^{*}$ & - & - & 17 & $\mathrm{P}_{\mathrm{j}}=0.74$ \\
\hline & Alt Grup & - & 3 & $8^{*}$ & 5 & 1 & 17 & $\mathrm{rj} x=0.53$ \\
\hline 22 & Üst Grup & - & 2 & - & $15^{*}$ & - & 17 & $\mathrm{P}_{\mathrm{j}}=0.47$ \\
\hline & Alt Grup & 8 & 3 & 4 & $1^{*}$ & 1 & 17 & $\mathrm{rj} x=0.82$ \\
\hline $23^{* *}$ & Üst Grup & $9^{*}$ & 3 & 3 & 2 & - & 17 & $\mathrm{P}_{\mathrm{j}}=0.47$ \\
\hline & Alt Grup & $7^{*}$ & 4 & 2 & 3 & 1 & 17 & $\mathrm{rj} x=0.14$ \\
\hline 24 & Üst Grup & - & 2 & $13^{*}$ & 2 & - & 17 & $\mathrm{P}_{\mathrm{j}}=0.47$ \\
\hline & Alt Grup & 2 & 1 & $3^{*}$ & 10 & 1 & 17 & $\mathrm{rj} x=0.59$ \\
\hline $25^{* *}$ & Üst Grup & $9^{*}$ & 4 & 4 & - & - & 17 & $\mathrm{P}_{\mathrm{j}}=0.44$ \\
\hline & Alt Grup & $6^{*}$ & 4 & 5 & 1 & 1 & 17 & $\mathrm{rj} x=0.18$ \\
\hline $26^{* *}$ & Üst Grup & 1 & - & 3 & $13^{*}$ & - & 17 & $\mathrm{P}_{\mathrm{j}}=0.41$ \\
\hline & Alt Grup & 4 & 3 & 2 & $7^{*}$ & 1 & 17 & $\mathrm{rj} x=0.12$ \\
\hline 27 & Üst Grup & 1 & 1 & 2 & $10^{*}$ & 3 & 17 & $\mathrm{P}_{\mathrm{j}}=0.38$ \\
\hline & Alt Grup & 1 & 7 & 5 & $3^{*}$ & 1 & 17 & $r j x=0.41$ \\
\hline 28 & Üst Grup & - & $16^{*}$ & - & 1 & - & 17 & $\mathrm{P}_{\mathrm{j}}=0.65$ \\
\hline & Alt Grup & 4 & $6^{*}$ & 2 & 4 & 1 & 17 & $\mathrm{rj} x=0.59$ \\
\hline $29 * *$ & Üst Grup & 1 & 2 & $12^{*}$ & 2 & - & 17 & $\mathrm{P}_{\mathrm{j}}=0.65$ \\
\hline & Alt Grup & 3 & 2 & 10 & 2 & - & 17 & $\mathrm{rj} x=0.12$ \\
\hline $30^{* *}$ & Üst Grup & $8^{*}$ & 6 & 3 & - & - & 17 & $\mathrm{P}_{\mathrm{j}}=0.41$ \\
\hline & Alt Grup & $6^{*}$ & 6 & 4 & 1 & - & 17 & $r j x=0.12$ \\
\hline
\end{tabular}


rje Maddenin ayırt edicilik gücü((Maddeyi üst grupta doğru cevaplayanlar - Maddeyi alt grupta doğru cevaplayanlar) / Üst ya da alt gruptan herhangi birisinin eleman sayısı

Birinci uygulama test geliştirme sürecinde olduğu gibi bu uygulamada da elde edilen veriler Microsoft Excel programına girilerek, test maddelerinin güçlük dereceleri, standart sapmaları ve ayırıcılık dereceleri hesaplanmıştır. Ayırıcılık dereceleri 0.20 ve altında olan maddeler (11, 23, 25, 29 ve 30) testten çıkarılmıştır (Turgut, 1992) (Tablo 10;Tablo 11).

Tablo 10. Üst ve alt gruptaki öğrencilerin doğru sayısına göre ikinci uygulama başarı testinin madde analizi

\begin{tabular}{|c|c|c|c|c|c|c|c|c|c|c|c|c|c|c|c|}
\hline$\frac{\pi}{\frac{\pi}{\pi}}$ & dü & da & pj & 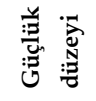 & rjx & $\begin{array}{l}\text { Ŭ } \\
\text { ڤ్ }\end{array}$ & 롤 & $\frac{\pi}{\pi}$ & dü & da & pj & 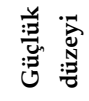 & rjx & $\begin{array}{l}\text { Ũ } \\
\text { ஸे }\end{array}$ & $\stackrel{\Xi}{\Xi}$ \\
\hline 1 & 17 & 12 & 0.85 & ÇK & 0.29 & Düz & - & 16 & 16 & 8 & 0.71 & $\mathrm{~K}$ & 0.47 & Çİ & $\sqrt{ }$ \\
\hline 2 & 16 & 11 & 0.79 & $\mathrm{~K}$ & 0.29 & Düz & - & 17 & 16 & 3 & 0.56 & $\mathrm{O}$ & 0.76 & Çİ & $\sqrt{ }$ \\
\hline 3 & 16 & 6 & 0.65 & K & 0.59 & Çİ & $\sqrt{ }$ & 18 & 16 & 2 & 0.53 & $\mathrm{O}$ & 0.82 & Çİ & $\sqrt{ }$ \\
\hline 4 & 17 & 6 & 0.68 & $\mathrm{~K}$ & 0.65 & Çİ & $\sqrt{ }$ & 19 & 16 & 1 & 0.50 & $\mathrm{O}$ & 0.88 & Çİ & $\sqrt{ }$ \\
\hline 5 & 15 & 8 & 0.68 & $\mathrm{~K}$ & 0.41 & Çİ & $\sqrt{ }$ & 20 & 15 & 4 & 0.56 & $\mathrm{O}$ & 0.65 & çİ & $\sqrt{ }$ \\
\hline 6 & 14 & 7 & 0.62 & $\mathrm{O}$ & 0.41 & Çİ & $\sqrt{ }$ & 21 & 17 & 8 & 0.74 & K & 0.53 & Çİ & $\sqrt{ }$ \\
\hline 7 & 16 & 5 & 0.62 & $\mathrm{O}$ & 0.65 & Çİ & $\sqrt{ }$ & 22 & 15 & 1 & 0.47 & $\mathrm{O}$ & 0.82 & ÇI் & $\sqrt{ }$ \\
\hline 8 & 16 & 2 & 0.53 & $\mathrm{O}$ & 0.82 & Çİ & $\sqrt{ }$ & 23 & 9 & 7 & 0.47 & O & 0.14 & Çık & - \\
\hline 9 & 17 & 3 & 0.59 & $\mathrm{O}$ & 0.82 & Çİ & $\sqrt{ }$ & 24 & 13 & 3 & 0.47 & $\mathrm{O}$ & 0.59 & Çİ & $\sqrt{ }$ \\
\hline 10 & 14 & 5 & 0.56 & $\mathrm{O}$ & 0.53 & Çİ & $\sqrt{ }$ & 25 & 9 & 6 & 0.44 & O & 0.18 & Çık & - \\
\hline 11 & 7 & 6 & 0.38 & O & 0.06 & Çık & - & 26 & 13 & 7 & 0.59 & $\mathrm{O}$ & 0.35 & $\dot{\mathrm{I}}$ & $\sqrt{ }$ \\
\hline 12 & 15 & 5 & 0.59 & $\mathrm{O}$ & 0.59 & Çİ & $\sqrt{ }$ & 27 & 10 & 3 & 0.38 & $\mathrm{O}$ & 0.41 & Çİ & $\sqrt{ }$ \\
\hline 13 & 16 & 10 & 0.76 & $\mathrm{~K}$ & 0.35 & $\dot{\mathrm{I}}$ & $\sqrt{ }$ & 28 & 16 & 6 & 0.65 & K & 0.59 & Çİ & $\sqrt{ }$ \\
\hline 14 & 16 & 4 & 0.59 & $\mathrm{O}$ & 0.71 & Çİ & $\sqrt{ }$ & 29 & 12 & 10 & 0.65 & K & 0.12 & Çık & - \\
\hline 15 & 16 & 5 & 0.62 & $\mathrm{O}$ & 0.65 & Çİ & $\sqrt{ }$ & 30 & 8 & 6 & 0.41 & O & 0.12 & Çık & - \\
\hline
\end{tabular}

ÇK: Çok Kolay, K: Kolay, O: Orta, Z: Zor, ÇZ: Çok zor, Çİ: Çok iyi, İ: İyi, Çık: Çıkarılmalı, Düz: Düzeltilmeli

Veriler için, birinci uygulamada olduğu gibi; çift serili korelasyon hesaplanmıştır.

Tablo 11. Taslak başarı testi ikinci uygulamasında yer alan maddelerin çift serili korelasyon katsayısı değerleri

\begin{tabular}{lllllllll}
\hline $\begin{array}{l}\text { Madde } \\
\text { No }\end{array}$ & $\mathbf{N}$ & $\mathbf{p}$ & $\mathbf{q}$ & $\overline{\mathbf{Y}} \mathbf{p}$ & $\overline{\mathbf{Y}} \mathbf{q}$ & $\mathbf{S S}$ & $\mathbf{p q} / \mathbf{y}$ & $\mathbf{r}_{\mathbf{s}}$ \\
\hline $\mathbf{1}$ & 62 & 0.90 & 0.10 & 17.40 & 10.33 & 0.30 & .513 & 0.56 \\
$\mathbf{2}$ & 62 & 0.79 & 0.21 & 17.86 & 13.38 & 0.41 & .576 & 0.40 \\
$\mathbf{3}$ & 62 & 0.69 & 0.31 & 18.77 & 12.74 & 0.46 & .353 & 0.33 \\
$\mathbf{4}$ & 62 & 0.73 & 0.27 & 19.02 & 11.35 & 0.45 & .331 & 0.39 \\
$\mathbf{5}$ & 62 & 0.73 & 0.27 & 18.91 & 11.65 & 0.45 & .331 & 0.37 \\
$\mathbf{6}^{*}$ & 62 & 0.68 & 0.32 & 18.55 & 13.50 & 0.47 & .358 & $\mathbf{0 . 2 8}$ \\
$\mathbf{7}$ & 62 & 0.74 & 0.26 & 18.76 & 11.63 & 0.44 & .324 & 0.36 \\
$\mathbf{8}$ & 62 & 0.48 & 0.52 & 21.20 & 12.91 & 0.50 & .396 & 0.51 \\
$\mathbf{9}$ & 62 & 0.53 & 0.47 & 20.70 & 12.62 & 0.50 & .398 & 0.49 \\
$\mathbf{1 0}$ & 62 & 0.55 & 0.45 & 19.47 & 13.82 & 0.50 & .396 & 0.34 \\
$\mathbf{1 1}$ & 62 & 0.37 & 0.63 & 15.48 & 17.05 & 0.49 & .378 & $\mathbf{0 . 0 9}$ \\
$\mathbf{1 2}$ & 62 & 0.56 & 0.44 & 19.77 & 13.22 & 0.50 & .394 & 0.40 \\
$\mathbf{1 3}$ & 62 & 0.44 & 0.56 & 19.74 & 14.74 & 0.50 & .396 & 0.30 \\
$\mathbf{1 4}$ & 62 & 0.58 & 0.42 & 20.22 & 12.35 & 0.50 & .391 & 0.47 \\
$\mathbf{1 5}$ & 62 & 0.66 & 0.34 & 19.44 & 12.00 & 0.48 & .366 & 0.42 \\
$\mathbf{1 6}$ & 62 & 0.60 & 0.40 & 19.65 & 12.88 & 0.49 & .386 & 0.40 \\
$\mathbf{1 7}$ & 62 & 0.65 & 0.35 & 19.80 & 11.68 & 0.48 & .370 & 0.46 \\
$\mathbf{1 8}$ & 62 & 0.56 & 0.44 & 20.23 & 12.63 & 0.50 & .394 & 0.46 \\
$\mathbf{1 9}$ & 62 & 0.50 & 0.50 & 21.61 & 12.23 & 0.50 & .399 & 0.58 \\
\hline
\end{tabular}


Aymen-Peker \& Taş

\begin{tabular}{lllllllll}
\hline $\begin{array}{l}\text { Madde } \\
\text { No }\end{array}$ & $\mathbf{N}$ & $\mathbf{p}$ & $\mathbf{q}$ & $\overline{\mathbf{Y}} \mathbf{p}$ & $\overline{\mathbf{Y}} \mathbf{q}$ & $\mathbf{S S}$ & $\mathbf{p q} / \mathbf{y}$ & $\mathbf{r}_{\mathbf{s}}$ \\
\hline $\mathbf{2 0}$ & 62 & 0.52 & 0.48 & 20.19 & 13.43 & 0.50 & .398 & 0.41 \\
$\mathbf{2 1}$ & 62 & 0.44 & 0.56 & 20.93 & 13.83 & 0.50 & .394 & 0.43 \\
$\mathbf{2 2}$ & 62 & 0.45 & 0.55 & 21.14 & 13.44 & 0.50 & .396 & 0.47 \\
$\mathbf{2 3}$ & 62 & 0.37 & 0.63 & 18.35 & 16.08 & 0.49 & .378 & $\mathbf{0 . 1 3}$ \\
$\mathbf{2 4}$ & 62 & 0.47 & 0.53 & 19.76 & 14.42 & 0.50 & .398 & 0.33 \\
$\mathbf{2 5}$ & 62 & 0.39 & 0.61 & 18.63 & 15.84 & 0.49 & .384 & $\mathbf{0 . 1 6}$ \\
$\mathbf{2 6}$ & 62 & 0.32 & 0.68 & 21.80 & 14.60 & 0.47 & .358 & 0.40 \\
$\mathbf{2 7}$ & 62 & 0.24 & 0.76 & 22.20 & 15.23 & 0.43 & .311 & 0.33 \\
$\mathbf{2 8}$ & 62 & 0.66 & 0.34 & 18.98 & 12.90 & 0.48 & .366 & 0.34 \\
$\mathbf{2 9 *}$ & 62 & 0.68 & 0.32 & 18.38 & 13.85 & 0.47 & .358 & $\mathbf{0 . 2 5}$ \\
$\mathbf{3 0}$ & 62 & 0.65 & 0.35 & 18.33 & 14.36 & 0.48 & .370 & $\mathbf{0 . 2 3}$ \\
\hline${ }^{*}$ Madde toplam puan korelasyonu 0.30'un altında olan maddeler & & &
\end{tabular}

Başarı testinde yer alan her bir maddenin çift serili korelasyon katsayı değeri hesaplandığında $6,11,23,25,29$ ve 30. maddelerin korelasyon katsayı değerleri 0.30 'un altındadır (Tablo 11). Bu soru maddelerinden 11, 23, 25, 29 ve 30. maddeler daha önce yapılan madde güçlük ve ayırt edicilik hesaplamasında düşük çıkarak elenen maddelerdir. 6 . madde değeri 0.28 olarak belirlendiği için testte yer almasına karar verilmiştir.

Bu uygulama sonunda test madde sayısı 25'e düşürülmüştür. Formül-3 kullanılarak hesaplanan KR-20 güvenirlik katsayısı 0.87 olarak tespit edilmiştir.

Tablo 12. Madde analizi sonucunda bulunan KTT istatistikleri

\begin{tabular}{|c|c|c|c|c|c|c|c|}
\hline $\begin{array}{c}\text { Kavram Tanı Testi (KTT) } \\
\text { 1.Aşama Soruları }\end{array}$ & $\begin{array}{c}\text { Madde } \\
\text { Sayısı }\end{array}$ & $\mathbf{N}$ & $\bar{x}$ & $\begin{array}{c}\text { Varyans } \\
\left(S^{2}\right)\end{array}$ & $\begin{array}{c}\text { Standart } \\
\text { Sapma (S) }\end{array}$ & $\begin{array}{c}\text { Ort. } \\
\text { Güçlük } \\
\text { (P) }\end{array}$ & KR-20 \\
\hline 1.Uygulama & 40 & 73 & 26.47 & 43.09 & 6.56 & 0.65 & 0.85 \\
\hline 2.Uygulama & 30 & 62 & 16.92 & 42.27 & 6.50 & 0.59 & 0.86 \\
\hline Nihai Ölçek & 25 & 62 & 14.62 & 30.73 & 5.54 & 0.61 & 0.87 \\
\hline
\end{tabular}

KTT aritmetik ortalama, standart sapma, varyans, ortalama güçlük ve güvenirlik hesaplamaları Tablo 12'de görülmektedir. Öğrenci başarısı ölçümünde kullanılacak testlerde testin ortalama güçlük indisinin 0.50 veya ona yakın bir değer olması gerekir (Çepni, Baki, Ayas, Demircioğlu \& Akyıldız, 2009). 25 soru şeklinde uygulanan test bu açıdan ölçülen özelliğe hizmet etmektedir. Aynı zamanda belirlenen testin güvenirlik katsayısı değeri de iç tutarlılığın yeterli düzeyde olduğunu gösteren 0.70 değerinden yüksektir. Bu durum da testin iç tutarlığının beklenen seviyede olduğunu göstermektedir.

\section{b. Kavram tanı testinin ikinci ve üçüncü aşama sorularının geliştirilmesi}

KTT 2. aşama soruları öğrencilerin birinci soruya verdikleri cevabın nedenini keşfetmeye yöneliktir. 2. aşama sorularının elde edilebilmesi için madde analizi sonrası 25 soru olarak düzenlenen test kullanılmıştır. Her bir test sorusundan sonra, öğrencilerin birinci aşama sorusuna verdikleri yanıtı seçme nedenini sorgulayan açı uçlu soru yazılmıştır. 
Öğrencilerin açık uçlu sorulara verdiği yanıtlar ve literatür taraması sonrasında üniteye ait belirlenen kavram yanılgıları dikkate alınarak ikinci aşama sorusunun seçenekleri belirlenmiştir. En sık tekrarlanan ifadeden başlamak üzere dört seçenek oluşturulmuş, beşinci olarak diğer seçeneği eklenmiştir. Test öğrencilere uygulanırken, öğrencinin birinci aşama sorusuna verdiği yanıtın nedeni, ona göre verilen diğer seçeneklerde yoksa öğrencinin bu şıkkı işaretlemesi ve kendi nedenini yazması istenmiştir (Şekil 2).

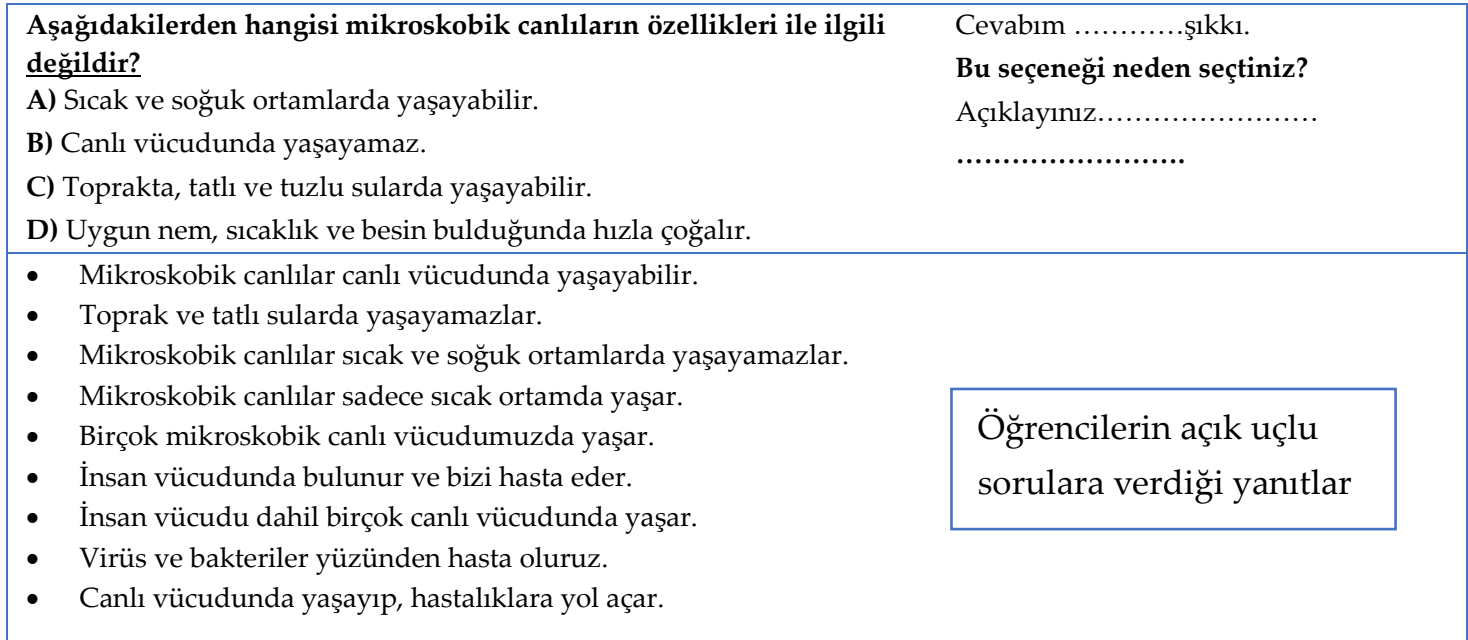

Şekil 2. İkinci aşama sorusu geliştirilmesi

Testin 3. aşama soruları ise öğrencinin 2. aşama sorusuna verdiği yanıttan ne kadar emin olduğunu tespit etmeye yöneliktir. Testteki bir test maddesi Şekil 3Şekil 3'de görülmektedir.

Soru 3.1.

Aşağıdakilerden hangisi mikroskobik canlıların özellikleri ile ilgili değildir?

A) Sicak ve soğuk ortamlarda yaşayabilir.

B) Canlı vücudunda yaşayamaz.

C)Toprakta, tatlı ve tuzlu sularda yaşayabilir.

D)Uygun nem, sıcaklık ve besin bulduğunda hızla çoğalır.

Soru 3.2.

Bir önceki soruda seçtiğiniz cevabın nedeni aşağıdakilerden hangisidir?

A. Mikroskobik canlılar canlı vücudunda yaşayabilir.

B. Toprak ve tatlı sularda yaşayamazlar.

C. Mikroskobik canlılar sıcak ve soğuk ortamlarda yaşayamazlar.

D. Mikroskobik canlılar sadece sıcak ortamda yaşar.

E. Diğer

Soru 3.3.

Bir önceki soruda verdiğiniz cevaptan ne kadar eminsiniz?
A ) Eminim
B) Emin Değilim
C) Tahmin Ettim

Şekil 3. KTT'de yer alan üç aşamalı soru örneği

Öğrencinin üç aşamalı testte yer alan her üç aşama sorusuna verdiği yanıt dikkate 
alınarak, öğrencilerin test maddesinde ölçülmeye çalışılan kazanım ile ilgili bir kavram yanılgısına sahip olup olmadığı belirlenmelidir.

\section{Aşamalı KTT'nin Geçerlik ve Güvenirlik Analizi}

KTT toplam 210 öğrenciye uygulanmıştır. Test maddelerine öğrencilerin verdikleri yanıtlar MS Excel programına girilip, bu programda geliştirilen makro uygulamayla ilgili puanlar hesaplanmıştır. 3 aşamalı KTT'de sorunun her bir aşamasına verilen yanıt dikkate alınarak, Peşman ve Eryılmaz (2010) ile Arslan, Çiğdemoğlu ve Moseley'in (2012) tanımladığı gibi sekiz ayrı puan hesaplaması yapılmıştır. Bunlar; 1. aşama puanı, her iki aşama puanı, toplam puan, emin olma puanı, bilgi eksikliği puanı, 1.aşama; her iki aşama ve tüm aşama kavram yanılgısı puanları şeklindedir.

Bu puanların tespit edilmesinde Şekil 4'de yer alan kodlamalardan yararlanılmıştır.

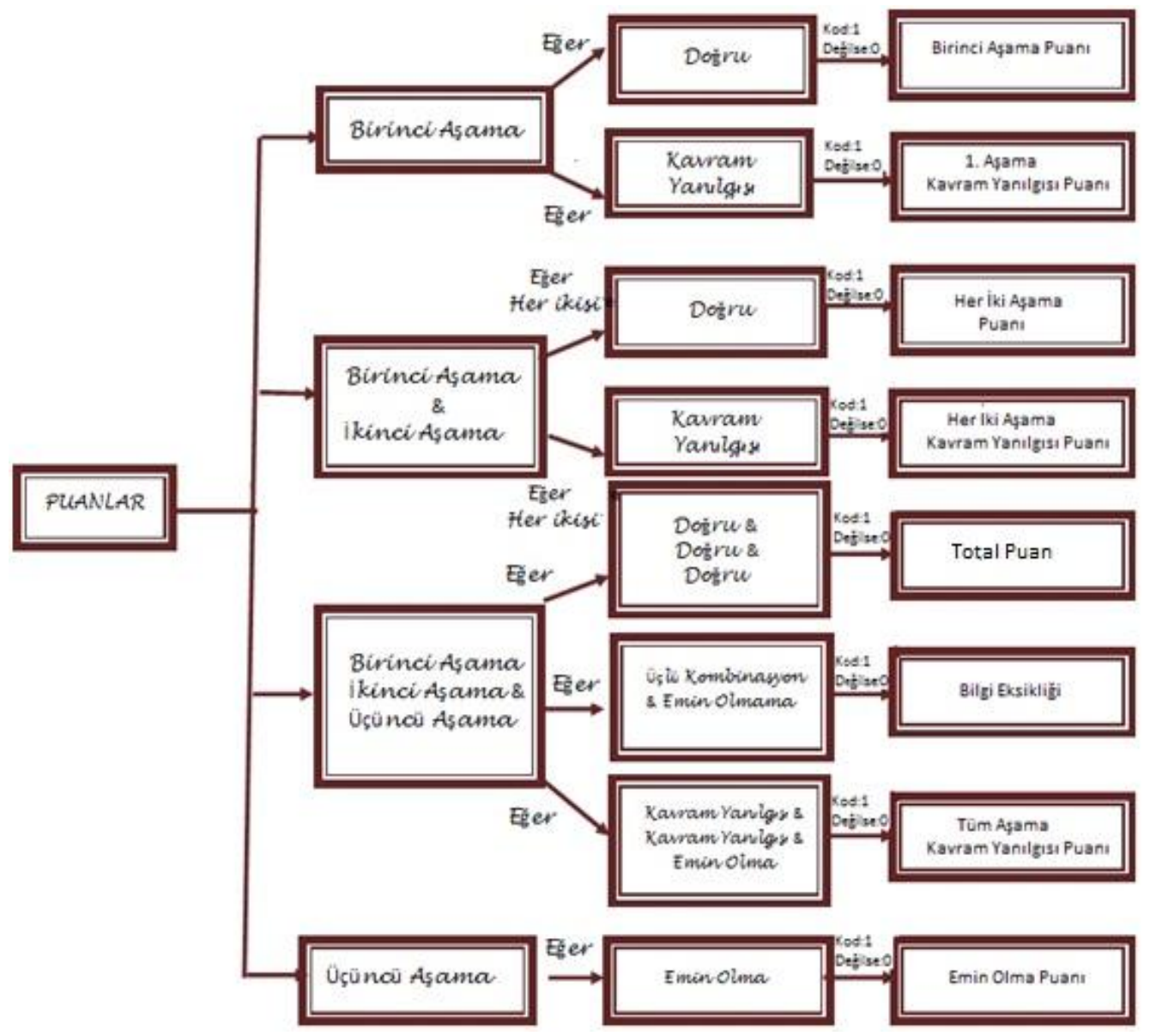

Şekil 4. Puanlama ve Kodlama prosedürü. Üçlü kombinasyon 'yanlış-doğru', 'doğru-yanlış' ve 'yanlışyanlış' (Arslan ve diğerlerinden (2012) uyarlanmıştır. 
Şekil 4'de gösterilen ve Tablo 13'de belirtildiği gibi gerçekleştirilen kodlamalar sonucunda, üç aşamalı test ile bilimsel bilgi, kavram yanılgısı, bilgi eksikliği ve şanslı cevap olmak üzere dört kategori için veriler elde edilmektedir (Tablo 13)

Tablo 13. Üç aşamalı testte mümkün olan olası yanıtlar ve bunların kategorileri

\begin{tabular}{llll}
\hline Birinci Aşama & İkinci Aşama & Üçüncü Aşama & Kategoriler \\
\hline Doğru & Doğru & Emin & Bilimsel Bilgiye Sahip \\
Doğru & Yanlşs & Emin değil & Bilgi Eksikliği \\
Yanlış & Doğru & Emin değil & Bilgi Eksikliği \\
Yanlşs & Yanlşş & Emin değil & Bilgi Eksikliği \\
Doğru & Doğru & Emin değil & Tahmini Şanslı cevap \\
Doğru & Yanlış & Emin & Kavram Yanılgisı (Pozitif yönde Yanlış) \\
Yanlış & Doğru & Emin & Kavram Yanılgisı (Negatif yönde Yanlış) \\
Yanlış & Yanlış & Emin & Kavram Yanılgısı \\
\hline
\end{tabular}

Tek aşama, iki aşama ve üç aşama durumlarına göre öğrencilerin madde başarı oranları Şekil 5'de görülmektedir.

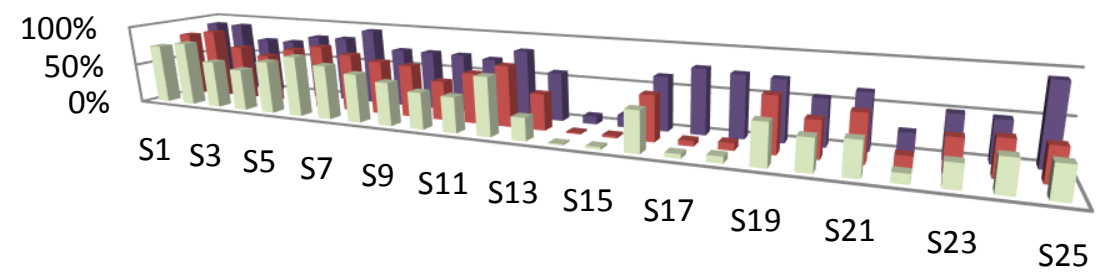

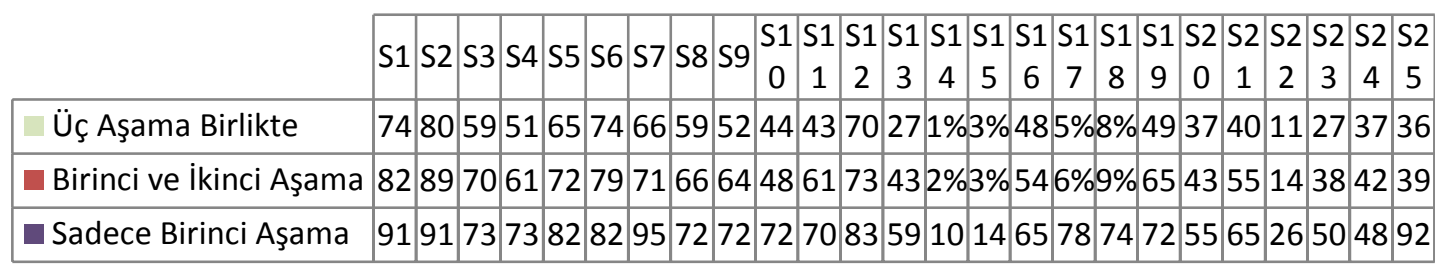

Şekil 5. KTT madde doğru cevaplandırma oranları

Şekil 5 incelendiğinde soru tek aşama olarak değerlendirildiğinde doğru cevaplandırma oranı en yüksek düzeydedir. 14, 15, 17, 18 ve 22. sorular iki aşama ve tüm aşamalar birlikte değerlendirildiğinde başarı oranı düşük olan sorular olduğu görülmektedir. KTT ile ilgili genel tanımlayıcı istatistikler SPSS paket programına veriler aktarıldıktan sonra elde edilmiştir. Testte üç aşama birlikte değerlendirildiğinde başarı ortalamasının tek aşamalı duruma göre düştüğü, KR-20 güvenilirlik düzeyinin arttığ1 görülmektedir (Tablo 14). Güvenirlik katsayısı 1'e yaklaştıkça, güvenilirlik düzeyi artar.

Tablo 14. KTT soruların güçlük ve ayırt edicilik değerleri

\begin{tabular}{lrrrrrrrr}
\hline \multirow{2}{*}{ Madde No: } & \multicolumn{2}{c}{ 1.Aşama Puanı } & \multicolumn{3}{c}{ Sadece 2. Aşama Puanı } & Her iki Aşama Puanı & \multicolumn{2}{c}{ Total Puan } \\
\cline { 2 - 9 } & $\mathbf{p j}$ & rjx & Pj & rjx & pj & rjx & pj & rjx \\
\hline 1 & 0.89 & 0.23 & 0.75 & 0.47 & 0.76 & 0.44 & 0.68 & 0.58 \\
2 & 0.91 & 0.14 & 0.85 & 0.23 & 0.85 & 0.23 & 0.79 & 0.25 \\
3 & 0.72 & 0.49 & 0.69 & 0.47 & 0.69 & 0.47 & 0.59 & 0.61 \\
4 & 0.71 & 0.51 & 0.59 & 0.58 & 0.59 & 0.58 & 0.49 & 0.63 \\
\hline
\end{tabular}


Aymen-Peker \& Taş

\begin{tabular}{lcccccccr}
\hline \multirow{2}{*}{ Madde No: } & \multicolumn{1}{c}{ 1.Aşama Puani } & \multicolumn{2}{c}{ Sadece 2. Aşama Puanı } & Her iki Aşama Puanı & \multicolumn{2}{c}{ Total Puan } \\
\cline { 2 - 9 } & $\mathbf{p j}$ & $\mathbf{r j x}$ & $\mathbf{P j}$ & $\mathbf{r j x}$ & $\mathbf{p j}$ & $\mathbf{r j x}$ & $\mathbf{p j}$ & rjx \\
\hline 5 & 0.82 & 0.30 & 0.70 & 0.46 & 0.70 & 0.46 & 0.61 & 0.56 \\
6 & 0.82 & 0.32 & 0.75 & 0.32 & 0.75 & 0.32 & 0.72 & 0.35 \\
7 & 0.94 & 0.12 & 0.69 & 0.54 & 0.69 & 0.54 & 0.66 & 0.54 \\
8 & 0.72 & 0.46 & 0.64 & 0.65 & 0.64 & 0.65 & 0.56 & 0.74 \\
9 & 0.73 & 0.47 & 0.60 & 0.60 & 0.60 & 0.60 & 0.53 & 0.67 \\
10 & 0.67 & 0.39 & 0.47 & 0.35 & 0.48 & 0.33 & 0.47 & 0.32 \\
11 & 0.70 & 0.56 & 0.59 & 0.79 & 0.60 & 0.77 & 0.43 & 0.72 \\
12 & 0.76 & 0.40 & 0.67 & 0.60 & 0.66 & 0.61 & 0.63 & 0.63 \\
13 & 0.58 & 0.67 & 0.46 & 0.77 & 0.46 & 0.77 & 0.34 & 0.65 \\
14 & 0.10 & 0.05 & 0.02 & 0.04 & 0.02 & 0.04 & 0.01 & 0.02 \\
15 & 0.11 & 0.05 & 0.04 & 0.04 & 0.04 & 0.04 & 0.03 & 0.02 \\
16 & 0.61 & 0.74 & 0.53 & 0.77 & 0.53 & 0.77 & 0.52 & 0.86 \\
17 & 0.74 & 0.49 & 0.04 & 0.09 & 0.04 & 0.07 & 0.02 & 0.04 \\
18 & 0.68 & 0.56 & 0.05 & 0.11 & 0.04 & 0.09 & 0.04 & 0.07 \\
19 & 0.66 & 0.68 & 0.56 & 0.84 & 0.56 & 0.84 & 0.50 & 0.89 \\
20 & 0.57 & 0.40 & 0.43 & 0.61 & 0.44 & 0.60 & 0.38 & 0.61 \\
21 & 0.60 & 0.63 & 0.52 & 0.68 & 0.52 & 0.68 & 0.42 & 0.74 \\
22 & 0.30 & 0.28 & 0.25 & 0.21 & 0.25 & 0.21 & 0.22 & 0.20 \\
23 & 0.52 & 0.58 & 0.40 & 0.49 & 0.41 & 0.47 & 0.32 & 0.47 \\
24 & 0.47 & 0.46 & 0.41 & 0.51 & 0.42 & 0.49 & 0.34 & 0.51 \\
25 & 0.90 & 0.19 & 0.47 & 0.46 & 0.47 & 0.46 & 0.41 & 0.44 \\
ORTALAMA & 0.65 & 0.40 & 0.49 & 0.46 & 0.49 & 0.47 & 0.43 & 0.48 \\
\hline
\end{tabular}

Verilerin analizi sonucunda her maddenin güçlük ve ayırt edicilik değerleri I. aşama, sadece II. aşama, her iki aşama puanı ve total puanlar için ayrı ayrı hesaplanmış Tablo 15'de sunulmuştur.

Tablo 15. Genel tanımlayıcı istatistikler

\begin{tabular}{lrrr}
\hline & Tek Aşama Puanı & İki Aşama Puanı & Üç Aşama Puanı \\
\hline Öğrenci Sayısı & 210 & 210 & 210 \\
Madde Sayısı & 25 & 25 & 25 \\
Ortalama & 16.64 & 12.49 & 10.66 \\
Standart Sapma & 4.002 & 4.539 & 4.788 \\
Varyans & 16.022 & 20.605 & 22.933 \\
Çarpıklık & -.575 & -.398 & -.046 \\
Basıklık & -.328 & -.701 & -1.050 \\
Minimum & 4.00 & 2.00 & 2.00 \\
Maksimum & 23.00 & 21.00 & 21.00 \\
Güvenilirlik (KR-20) & 0.78 & 0.81 & 0.83 \\
\hline
\end{tabular}

Tablo incelendiğinde $14,15,17$ ve 18 . soruların rjx değerlerinin 0.20 'nin altında olduğu, pj değerinin de çok düşük olduğu gözlenmektedir. Madde güçlük ve ayırt edicilik değerleri, dört ayrı şekilde hesaplandığında, yüzde değerleri açısından farklılıklar olmakla birlikte, 14 ve 15 . maddelerin ilgili puanlarının dört puanlamada da düşük olduğu dikkat çekmektedir.

Veriler SPSS programına aktarıldıktan sonra, testin 1. aşama puanları dikkate alınarak testin toplamından alınan puan (sürekli değişken) ile testin her maddesinden alınan puan arasındaki ilişki çift serili korelasyon şeklinde hesaplandığında 14 ve 15 . maddelerin korelasyon katsayı değerleri 0.30'un altındadır (Tablo 16). Bu maddeler, güçlük ve ayırt 
edicilik hesaplamasında da düşük çıkarak elenen maddeler (Tablo 15) olduğu için, testten çıkarılmış, test madde sayısı 23'e düşürülmüştür.

Tablo 16. KTT 1.aşama puanları-maddelerin çift serili korelasyon katsayı değerleri (n=210)

\begin{tabular}{|c|c|c|c|c|c|c|c|c|c|c|c|c|c|c|c|}
\hline $\begin{array}{l}\frac{0}{\pi} \\
\frac{\pi}{2}\end{array}$ & p & $\mathbf{Q}$ & $\overline{\mathbf{Y}} \mathbf{p}$ & $\overline{\mathbf{Y}} \mathbf{q}$ & SS & $\mathrm{pq} / \mathrm{y}$ & $\mathbf{r}_{\varsigma}$ & $\frac{\pi}{\frac{\pi}{\pi}}$ & $p$ & $\mathbf{Q}$ & $\overline{\mathbf{Y}} \mathbf{p}$ & $\overline{\mathbf{Y}} \mathbf{q}$ & SS & $\mathrm{pq} / \mathrm{y}$ & $\mathbf{r}_{\varsigma}$ \\
\hline 1 & 0.91 & 0.09 & 16.99 & 13.11 & 0.29 & 0.504 & 0.49 & 14 & 0.10 & 0.90 & 15.40 & 16.77 & 0.29 & 0.513 & -0.18 \\
\hline 2 & 0.91 & 0.09 & 16.94 & 13.63 & 0.29 & 0.504 & 0.42 & 15 & 0.14 & 0.86 & 16.13 & 16.72 & 0.35 & 0.541 & -0.08 \\
\hline 3 & 0.73 & 0.27 & 17.69 & 13.82 & 0.45 & 0.596 & 0.58 & 16 & 0.65 & 0.35 & 18.50 & 13.22 & 0.48 & 0.614 & 0.81 \\
\hline 4 & 0.73 & 0.27 & 17.72 & 13.74 & 0.45 & 0.596 & 0.59 & 17 & 0.78 & 0.22 & 17.71 & 12.91 & 0.42 & 0.58 & 0.70 \\
\hline 5 & 0.82 & 0.18 & 17.26 & 13.84 & 0.39 & 0.563 & 0.48 & 18 & 0.74 & 0.26 & 17.85 & 13.13 & 0.44 & 0.593 & 0.70 \\
\hline 6 & 0.82 & 0.18 & 17.24 & 13.84 & 0.38 & 0.563 & 0.48 & 19 & 0.72 & 0.28 & 18.14 & 12.71 & 0.45 & 0.599 & 0.81 \\
\hline 7 & 0.95 & 0.05 & 16.85 & 12.40 & 0.21 & 0.461 & 0.51 & 20 & 0.55 & 0.45 & 17.81 & 15.22 & 0.50 & 0.625 & 0.40 \\
\hline 8 & 0.72 & 0.28 & 17.72 & 13.81 & 0.45 & 0.599 & 0.58 & 21 & 0.65 & 0.35 & 18.14 & 13.82 & 0.48 & 0.614 & 0.66 \\
\hline 9 & 0.72 & 0.28 & 17.82 & 13.55 & 0.45 & 0.599 & 0.64 & 22 & 0.30 & 0.60 & 17.70 & 16.27 & 0.44 & 0.593 & 0.21 \\
\hline 10 & 0.72 & 0.28 & 17.56 & 14.29 & 0.45 & 0.599 & 0.49 & 23 & 0.50 & 0.50 & 18.32 & 14.95 & 0.50 & 0.627 & 0.53 \\
\hline 11 & 0.70 & 0.30 & 17.92 & 13.70 & 0.46 & 0.604 & 0.64 & 24 & 0.48 & 0.52 & 18.14 & 15.25 & 0.50 & 0.626 & 0.45 \\
\hline 12 & 0.83 & 0.17 & 17.56 & 12.17 & 0.38 & 0.568 & 0.77 & 25 & 0.92 & 0.08 & 16.89 & 13.76 & 0.27 & 0.495 & 0.39 \\
\hline 13 & 0.59 & 0.41 & 18.47 & 14.00 & 0.49 & 0.622 & 0.69 & & & & & & & & \\
\hline
\end{tabular}

Son durumda hesaplanan KR-20 güvenirlik katsayısı 0.80 'dir. Üç madde birlikte değerlendirildiğinde testin güçlük ve ayırt edicilik değerleri ise sırasıyla pj: 0.47 ve rjx: 0.52 'dir.

Tablo 17. Nihai KTT'de yer alan soru maddelerinin konulara ve kazanımlara göre dağılımı

\begin{tabular}{llll}
\hline Konular & Kazanımlar & Madde Numarası & Madde Sayısı \\
\hline Canlıları Tanıyalım & 5.5 .1 .1$. & $1,2,3,4,5,6,7,9,18,23,25$ & 11 \\
İnsan ve Çevre İlişkisi & 5.5 .2 .1$. & $8,10,11,12,13,17,19,20,21,22,24$ & 11 \\
& 5.5 .2 .2$. & 16 & 1 \\
\hline
\end{tabular}

\section{Sonuç}

$\mathrm{Bu}$ çalışma sonucunda 5.sınıf öğrencilerinin Canlılar Dünyasını Gezelim ve Tanıyalım ünitesi kazanımlarına ne düzeyde ulaştıklarını ve ünite ile ilgili ne tür kavram yanılgılarına sahip olduklarını tespit edebilmek amacıyla kullanılacak üç aşamalı başarı testi geliştirilip, ölçeğin geçerlik ve güvenirlik çalışmaları tamamlanmıştır. Başlangıçta 40 madde olarak geliştirilen teste, geçerlik ve güvenirlik çalışmaları sonucunda 23 madde içerecek şekilde son şekli verilmiştir.

Test güvenirliği KR-20 formülü ile hesaplanmış; KR-20 güvenirlik düzeyinin ,80 olduğu tespit edilmiştir. Üç madde birlikte değerlendirildiğinde testin güçlük ve ayırt edicilik değerleri sırasıyla pj: 0.47 ve rjx: 0.52 olarak hesaplanmıştır. Bu veriler geliştirilen 
testin güvenilir, orta güçlükte ve çok iyi maddelerden oluşan bir yapıya sahip olduğunu göstermektedir.

Testte test maddeleri tek aşama, iki aşama ve üç aşama birlikte değerlendirilerek ayrı ayrı başarı ortalaması hesaplanmıştır. Başarı ortalaması üç aşama birlikte değerlendirildiğinde tek aşamalı duruma göre düşmesine rağmen, KR-20 güvenilirlik düzeyinin arttığı tespit edilmiştir (Şekil 5). Bu sonuç elde edilen testin güvenirliğini bir kez daha ortaya koymaktadir.

Tek aşamalı başarı testleri araştırmacı ya da öğretmenlere, kavramın öğrenilme düzeyini belirleyebilmeleri konusunda bilgi vermektedir. Ancak araştırma sonucu geliştirilen üç aşamalı test, araştırmacı ya da öğretmenlere kavramın öğrenilme düzeyini tespit etmenin yanı sıra, bilimsel bilgi, kavram yanılgısı, bilgi eksikliğine sahip olma ya da sorunun şans eseri cevaplanıp cevaplanmadığını tespit etme fırsatı sunmaktadır. Bu veriler de ilgili kişiler için daha fazla yol gösterici olacaktır.

\section{Öneriler}

- Yapılan analiz işlemleri sonucunda geçerliği ve güvenirliği ortaya konulan kavram tanı testi, 5.sınıf öğrencilerinin "Canlılar Dünyasını Gezelim ve Tanıyalım” ünitesi kazanımlarına ulaşıp ulaşmadıklarını ve hangi kavram yanılgılarına sahip olduğunu belirlemek için kullanılabilecek özelliktedir.

- Kavram tanı testi araştırmacıların tek bir ölçekle iki ayrı veri seti (akademik başarı ve kavram bilgisi) elde etme kolaylığı sağlayacaktır.

- Araştırmacılar, akademik başarı belirleme sürecinde ölçeğin sadece birinci aşama sorularını dikkate alabilecekleri gibi, üç aşamayı da dikkate alarak değerlendirme yapabilir. Kavram yanılgısı belirlemek amacıyla ölçekten yararlanacak araştırmacılar ise üç aşamayı birlikte değerlendirmelidir.

- Çalışma, üç aşamalı başarı testi/kavram tanı testi geliştirecek araştırmacılar için yol göstericidir.

\section{Bilgilendirme}

$\mathrm{Bu}$ çalışma Ondokuz Mayıs Üniversitesi Bilimsel Araştırma Projeleri kapsamında PYO.EGF.1904.14.006 no'lu proje olarak desteklenen ve birinci yazarın doktora tezinin bir parçasından oluşmaktadır. 


\section{Kaynaklar}

Allen, M. (2010). Misconceptions in primary science. Berkshire: Open University Press.

Arslan, H. O., Çiğdemoğlu, C. \& Moseley, C. (2012). A three-tier diagnostic test to assess preservice teachers' misconceptions about global warming, greenhouse effect, ozone layer depletion, and acid rain. International Journal of Science Education, 34 (11), 16671686. doi:10.1080/09500693.2012.680618

Bağcan-Büyükturan, E. \& Çıkrıkçı Demirtaşlı, S. (2012). Çoktan seçmeli testler ile yapılandırılmış gridlerin psikometrik özellikleri bakımından karşılaştırılması. Ankara Üniversitesi Eğitim Bilimleri Fakültesi Dergisi, 45 (1), 395-415.

Bakioğlu, B., Karamustafaoğlu, S. \& Karamustafaoğlu, O. (2014, Mayıs). 5. sinıf "Vücudumuzun bilmecesini çözelim" ünitesi başarı testi: geçerlik ve güvenirlik. Konya: International Conference On Education in Mathematics, Science \& Technology(ICEMST 2014) bildiri kitabı, 16-18 Mayıs, Konya.

Bernhisel, S. M. (1999). Measuring preservice and inservice biology teachers' understanding of selected biological concepts. Unpublished Dissertation. Utah: Utah State University

Büyüköztürk, Ş. (2010). Sosyal Bilimler için veri analizi el kitabı (12. bs.) Ankara: Pegem Akademi.

Büyüköztürk, Ş., Çokluk, O. \& Köklü, N. (2010). Sosyal bilimler için istatistik (6.bs.). Ankara: Pegem Akademi.

Chen, C.C., Lin, H.S., \& Lin, M.L. (2002). Developing a two-tier diagnostic instrument to assess high school students' understanding-the formation of images by a plane mirror. Proceedings of the National Science Council, 12 (3), 106-121.

Çalık, M. \& Ayas, A. (2003). Çözeltilerde kavram başarı testi hazırlama ve uygulama. Pamukkale Üniversitesi Ĕ̆itim Fakültesi Dergisi, 14 (2), 1-17.

Çelik, D. (2000). Okullarda ölçme ve değerlendirme nasıl olmalı? İstanbul: Milli Eğitim Basımevi.

Çepni, S., Baki, A., Ayas, A., Demircioğlu, G., \& Akyıldız, S. (2009). Ölçme ve değerlendirme. Trabzon: Celepler Matbaacilık.

Çetinkaya, M. (2010). Canlıların sınıflandırılması konusu için web destekli kavram haritaları ve anlam çözümleme tablolarının öğrenme üzerindeki etkisinin araştırılması (Yayımlanmamış yüksek lisans tezi), Ondokuz Mayıs Üniversitesi Fen Bilimleri Enstitüsü, Samsun.

Gönen, S., Kocakaya, S. \& Kocakaya, F. (2011). Dinamik konusunda geçerliliği ve güvenilirliği sağlanmış bir başarı testi geliştirme çalışması. Yüzüncü Yıl Üniversitesi Eğitim Fakültesi Dergisi, 8 (1), 40-57.

Karataş, F. Ö., Köse S. \& Coştu, B., (2003). Öğrenci yanılgılarını ve anlama düzeylerini belirlemede kullanılan iki aşamalı testler. Pamukkale Eğitim Fakültesi Dergisi, 1 (13), 5469.

Mutlu, M. \& Tokcan, H. (2012). İlköğretim 7. sınıf öğrencilerinin toprak kirliliği hakkındaki düşünceleri. International Journal of Social Science Research, 1 (1), 65-75.

Novak, J. D. (1998). Metacognitive strategies to help students learning how to learn. Research Matters-to the Science Teacher, No.9802, Mart National Association for Research in 
Science Teaching. Erişim adresi:

https://www.narst.org/publications/research/Metacogn.cfm

Odom, A.L., \& Barrow, L.H. (1995). Development and application of a two tier diagnostic test measuring college biology students' understanding of diffusion and osmosis after a course of instruction, Journal of Research in Science Teaching, 32 (1), 45-61.

Öksüz, Y., \& Güven Demir, E. (2019). Açık uçlu ve çoktan seçmeli başarı testlerinin psikometrik özellikleri ve öğrenci performansı açısından karşılaştırılması. Hacettepe Üniversitesi Ĕ̆itim Fakültesi Dergisi, 34(1), 259-282. doi: 10.16986/HUJE.2018040550

Özçelik, D. A. (2010). Test hazırlama kılavuzu (4. baskı). Ankara: PegemA Yayıncılık.

Özyılmaz-Akamca, G. (2008). İlköğretimde analojiler, kavram karikatürleri ve tahmin-gözlemaçıklama teknikleriyle desteklenmiş fen ve teknoloji eğitiminin öğrenme ürünlerine etkisi (Yayımlanmamış doktora tezi). Dokuz Eylül Üniversitesi Eğitim Bilimleri Enstitüsü, İzmir.

Peşman, H. (2005). Development of a three-tier test to assess ninth grade students' misconceptions about simple electric circuits (Yayımlanmamış yüksek lisans tezi). Orta Doğu Teknik Üniversitesi Fen Bilimleri Enstitüsü, Ankara.

Peşman, H. \& Eryılmaz, A. (2010). Development of a three-tier test to assess misconceptions about simple electric circuits. Journal of Educational Research, 103 (3), 208-222.

Saka, A., Ayas, A. \& Enginar, İ. (2002, Eylül). Öğrencilerin omurgalı-omurgasız canlılar ile ilgili görüşlerinin yaşlara göre değişimi. 5. Ulusal Fen Bilimleri ve Matematik Eğitimi Kongresi. 16-18 Eylül, Ankara: ODTÜ.

Sesli, E. \& Kara, Y. (2012). Development and application of a two-tier multiple-choice diagnostic test for high school students' understanding of cell division and reproduction, Journal of Biological Education, 46 (4), 214-225.

Sözbilir, M. (2010). Madde analizi ve test geliştirme. Erişim adresi: https://olcmevedegerlendirme.files.wordpress.com/2010/09/7-madde-analizi-ve-testgelistirme.pdf

Summers, M., Kruger, C., Childs, A. \& Mant, J. (2000). Primary school teachers' understanding of environmental issues: An interview study. Environmental Education Research, 6 (4), 293-312.

Tan, K-C. D., Goh, N-K., Chia, L. S. \& Treagust, D. F. (2002). Development and application of a two-tier multiple-choice diagnostic instrument to assess high school students' understanding of inorganic chemistry qualitative analysis, Journal of Research in Science Teaching, 39 (4), 283-301.

Taş, E., Aymen Peker, E. \& Çetinkaya, M. (2014). Determining of misconceptions by means of tree-tier test about the unit human and environment. Proceedings of $2^{\text {nd }}$ International Conference on Economics and Social Sciences, 85-90.

Tavşancıl, E. (2010). Tutumların ölçülmesi ve SPSS ile veri analizi. Ankara: Nobel Yayın.

Tekkaya, C., Çapa, Y. \& Yılmaz, Ö. (2000). Biyoloji öğretmen adaylarının genel biyoloji konularındaki kavram yanılgıları. Hacettepe Üniversitesi Eğitim Fakültesi Dergisi, 18, 140-147. 
Yağbasan R. \& Gülçiçek Ç. (2003). Fen öğretiminde kavram yanılgılarının karakteristiklerinin tanımlanması. Pamukkale Üniversitesi Ĕ̆itim Fakültesi Dergisi, 13, 110 -128.

Yen, C-F., Yao, T-W. \& Mintzes, J-J. (2007). Taiwanese students' alternative conceptions of animal biodiversity. International Journal of Science Education, 29 (4), 535-553. 